\title{
Exceptional floods in the Prut basin, Romania, in the context of heavy rains in the summer of 2010
}

\author{
Gheorghe Romanescu and Cristian Constantin Stoleriu \\ Faculty of Geography and Geology, Department of Geography, Alexandru Ioan Cuza University of Iasi, \\ Bd. Carol I, 20 A, 700505 Iasi, Romania \\ Correspondence to: Gheorghe Romanescu (romanescugheorghe@gmail.com)
}

Received: 30 August 2016 - Discussion started: 12 September 2016

Revised: 4 January 2017 - Accepted: 13 February 2017 - Published: 10 March 2017

\begin{abstract}
The year 2010 was characterized by devastating flooding in central and eastern Europe, including Romania, the Czech Republic, Slovakia, and Bosnia-Herzegovina. This study focuses on floods that occurred during the summer of 2010 in the Prut River basin, which has a high percentage of hydrotechnical infrastructure. Strong floods occurred in eastern Romania on the Prut River, which borders the Republic of Moldova and Ukraine, and the Siret River. Atmospheric instability from 21 June to 1 July 2010 caused remarkable amounts of rain, with rates of $51.2 \mathrm{~mm} / 50 \mathrm{~min}$ and $42.0 \mathrm{~mm} / 30 \mathrm{~min}$. In the middle Prut basin, there are numerous ponds that help mitigate floods as well as provide water for animals, irrigation, and so forth. The peak discharge of the Prut River during the summer of 2010 was $2310 \mathrm{~m}^{3} \mathrm{~s}^{-1}$ at the Rădăuţi-Prut gauging station. High discharges were also recorded on downstream tributaries, including the Baseu, Jijia, and Miletin. High discharges downstream occurred because of water from the middle basin and the backwater from the Danube (a historic discharge of $16300 \mathrm{~m}^{3} \mathrm{~s}^{-1}$ ). The floods that occurred in the Prut basin in the summer of 2010 could not be controlled completely because the discharges far exceeded foreseen values.
\end{abstract}

\section{Introduction}

Catastrophic floods occurred during the summer of 2010 in central and eastern Europe. Strong flooding usually occurs at the end of spring and the beginning of summer. Among the most heavily affected countries were Poland, Romania, the Czech Republic, Austria, Germany, Slovakia, Hungary, Ukraine, Serbia, Slovenia, Croatia, Bosnia and Herzegov- ina, and Montenegro (Bissolli et al., 2011; Szalinska et al., 2014) (Fig. 1). The strongest floods from 2010 were registered in the Danube basin (see Table 1). For Romania, we underlined the floods from the basins of Prut, Siret, Moldova, and Bistriţa rivers. The most devastating floods in Romania occurred in Moldavia (Prut, Siret) and Transylvania (Tisa, Somes, Tarnave, Olt). The most deaths were recorded in Poland (25), Romania (six on the Buhai River, a tributary of the Jijia), Slovakia (three), Serbia (two), Hungary (two), and the Czech Republic (two) (Romanescu and Stoleriu, 2013a, b).

Floods are one of the most important natural hazards in Europe (Thieken et al., 2016) and on earth (Merz et al., 2010; Riegger et al., 2009). They generate major losses of human lives and also property damage (Wijkman and Timberlake, 1984). For this reason, they have been subject to intense research, and significant funds have been allocated to mitigating or stopping them. According to Merz et al. (2010) "the European Flood Directive on the assessment and management of flood risks (European Commission, 2007) requires developing management plans for areas with significant flood risk (at a river basin scale), focusing on the reduction of the probability of flooding and on the potential consequences to human health, the environment and economic activity." (p. 511). Several studies investigated catastrophic floods or the floods that generated significant damage. They focused on the statistical distribution of the maximum annual discharge using GEV and the links with the basin geology (Ahilan et al., 2012), climate change impacts on floods (Alfieri et al., 2015; Detrembleurs et al., 2015; Schneider et al., 2013; Whitfield, 2012), disastrous effects on infrastructures such as transportation infrastructures and their interdependence 


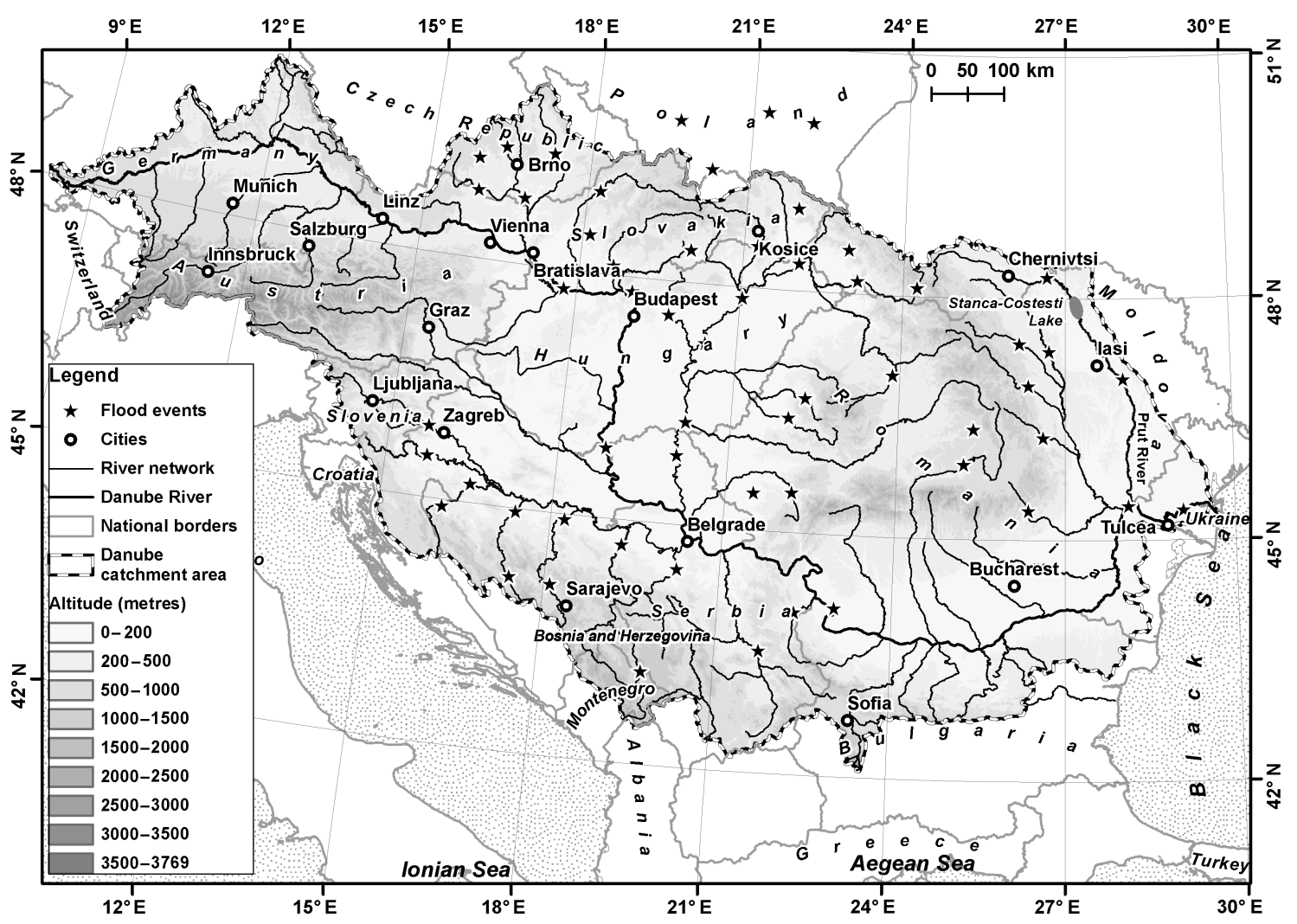

Figure 1. The Danube catchment and the location of the most important floods that occurred from May to June 2010.

(Berariu et al., 2015), historical floods (Blöschl et al., 2013; Strupczewski et al., 2014; Vasileski and Radevski, 2014) and their links to heavy rainfall (Bostan et al., 2009; Diakakis, 2011; Prudhomme and Genevier, 2011; Retsö, 2015), the public perception of flood risks (Brilly and Polic, 2005; Feldman et al., 2016; Rufat et al., 2015), land use changes and flooding (Cammerer et al., 2012), the evolution of natural risks (Hufschmidt et al., 2005), geomorphological effects of floods in riverbeds (Lichter and Klein, 2011; Lóczy and Gyenizse, 2011; Lóczy et al., 2009, 2014; Reza Ghanbarpour et al., 2014; Romanescu and Nicu, 2014), the spatial distribution of floods (de Moel et al., 2009; Parker and Fordham, 1996), and the interrelation between snow and flooding (Revuelto et al., 2013).

The Prut catchment basin spans three topographic levels: mountains, plateaus, and plains. The surface and underground water supply to the Prut varies by region and is extremely influenced by climatic conditions. This study underscores the role played by local heavy rains in the occurrence of floods, as well as the importance of ponds, mainly the Stânca-Costeşti reservoir, in the mitigation of backwaters. We also analyse the local contribution of each catchment basin on the right side of the Prut to the occurrence of the exceptional floods in the summer of 2010. Finally, we consider the upstream discharge and its influence on the lower reaches of the Prut.

\section{Study area}

The Prut River's catchment is situated in the north-eastern Danube basin. It is surrounded by several other catchments: the Tisa to the north-east (which spans Ukraine, Romania, and Hungary), the Siret to the west (which is partially in Ukraine), and the Dniestr (in the Republic of Moldova) to the north-east. The Prut catchment occupies eastern Romania and the western part of the Republic of Moldova (Fig. 2). The Prut River begins in the Carpathian Mountains in Ukraine and empties into the Danube near the city of Galati. The catchment measures $27500 \mathrm{~km}^{2}$, of which $10967 \mathrm{~km}^{2}$ lies in Romania (occupying approximately $4.6 \%$ of the surface of Romania).

The Prut River is the second longest river in Romania, at $952.9 \mathrm{~km}$ in length. It is a cross-border river, with $31 \mathrm{~km}$ in Ukraine and $711 \mathrm{~km}$ in the Republic of Moldova. The mean altitude of the midstream sector of catchment area is $130 \mathrm{~m}$, and for the downstream sector it is $2 \mathrm{~m}$. The Prut has 248 tributaries. Its maximum width is $12 \mathrm{~km}$ (in the lower reaches, Brates Lake) and its average slope is $0.2 \%$. Its hydrographic network measures $11000 \mathrm{~km}$ in total, of which $3000 \mathrm{~km}$ are permanent streams $(33 \%)$ and $8000 \mathrm{~km}$ are intermittent $(67 \%)$. The network has the highest density in Romania at $0.41 \mathrm{~km} \mathrm{~km}^{-2}$ (the average density is $0.33 \mathrm{~km} \mathrm{~km}^{-2}$ ). 
Table 1. Overview of main flood events for the Danube River basin in 2010, as forecasted by EFAS and/or reported in international online news media (ICPDR, 2010).

\begin{tabular}{|c|c|c|c|c|c|c|c|}
\hline $\begin{array}{l}\text { From } \\
\text { (dd.mm) }\end{array}$ & $\begin{array}{l}\text { To } \\
\text { (dd.mm) }\end{array}$ & $\begin{array}{l}\text { River basin } \\
\text { Affected }\end{array}$ & $\begin{array}{l}\text { Country } \\
\text { Affected }\end{array}$ & $\begin{array}{l}\text { EFAS } \\
\text { Alert sent? }\end{array}$ & $\begin{array}{l}\text { Date FAS } \\
\text { Alert sent }\end{array}$ & Confirmed? & Comment \\
\hline 20.II & 4.III & Sava & HR/RS & $\begin{array}{l}\text { Yes } \\
\text { (Flood Watch) }\end{array}$ & $24 \mathrm{Feb}$ & Yes & $\begin{array}{l}\text { Severe flooding in central and } \mathrm{E} \\
\text { Serbia, and in Sava and Morava } \\
\text { river systems. }\end{array}$ \\
\hline 21.II & 28.II & Velika Morava & RS & $\begin{array}{l}\text { Yes } \\
\text { (Flood watch) }\end{array}$ & $16 \mathrm{Feb}$ & Yes & Severe flooding in eastern Serbia \\
\hline Feb & Feb & Koeroes & $\mathrm{RO} / \mathrm{HU}$ & $\begin{array}{l}\text { Yes } \\
\text { (Flood watch) }\end{array}$ & $16 \mathrm{Feb}$ & No & $\begin{array}{l}\text { (No reports found on online news } \\
\text { media). Events to be confirmed by } \\
\text { partners in next annual EFAS meet- } \\
\text { ing }\end{array}$ \\
\hline 1.III & 5.III & Danube & $\mathrm{RO} / \mathrm{BG}$ & $\begin{array}{l}\text { Yes } \\
\text { (Flood alert) }\end{array}$ & 3 Mar & Yes & $\begin{array}{l}\text { Severe flooding in S Romania and } \\
\text { in NW and N Bulgaria. }\end{array}$ \\
\hline March & March & $\begin{array}{l}\text { Somes/Mures/ } \\
\text { Koeroes }\end{array}$ & $\mathrm{RO} / \mathrm{HU}$ & $\begin{array}{l}\text { Yes } \\
\text { (Flood alert) }\end{array}$ & 18 Mar & No & $\begin{array}{l}\text { No reports found on online news } \\
\text { media. Events to be confirmed by } \\
\text { partners in next annual EFAS meet- } \\
\text { ing }\end{array}$ \\
\hline $15 . \mathrm{V}$ & $30 . \mathrm{V}$ & Danube/Oder & $\mathrm{SK} / \mathrm{PL} / \mathrm{CZ} / \mathrm{HU}$ & $\begin{array}{l}\text { Yes } \\
\text { (Flood alert) }\end{array}$ & 12 May & Yes & $\begin{array}{l}\text { Extensive flooding in central and } \\
\text { eastern Europe, esp. Poland, Czech } \\
\text { Republic, Slovakia, Hungary, and } \\
\text { Serbia. }\end{array}$ \\
\hline Late June & July & $\begin{array}{l}\text { Siret/Prut/ } \\
\text { Moldova/ } \\
\text { Bistriţa }\end{array}$ & $\mathrm{RO} / \mathrm{MD}$ & No & - & Yes & $\begin{array}{l}\text { Severe flooding in NE Romania } \\
\text { kills } 25 \text { people, also some in coun- } \\
\text { ties in Moldova. }\end{array}$ \\
\hline 15.VII & 15.VII & Prut/Olt & RO & $\begin{array}{l}\text { Yes } \\
\text { (Flood alert) }\end{array}$ & 7 July & Yes & $\begin{array}{l}\text { Maximum flood alert on Prut River } \\
\text { in E Romania, along border with } \\
\text { Moldova. }\end{array}$ \\
\hline 17.IX & 19.IX & Sava/Soca & $\mathrm{HR} / \mathrm{SL}$ & $\begin{array}{l}\text { Yes } \\
\text { (Flood alert) }\end{array}$ & $18 \mathrm{Sep}$ & Yes & $\begin{array}{l}\text { Severe flooding in Slovenia kills } \\
\text { three people. Croatia also affected. }\end{array}$ \\
\hline Late Nov & Early Dec & Drina & RS & $\begin{array}{l}\text { Yes } \\
\text { (Flood alert) }\end{array}$ & $29 \mathrm{Nov}$ & Yes & $\begin{array}{l}\text { Severe flooding in Bosnia, Serbia, } \\
\text { and Montenegro, with river Drina at } \\
\text { highest level in } 100 \text { years. }\end{array}$ \\
\hline 3.XII & 8.XII & Sava & HR & $\begin{array}{l}\text { Yes } \\
\text { (Flood alert) }\end{array}$ & $5 \mathrm{Dec}$ & Yes & $\begin{array}{l}\text { Heavy rain causes devastating } \\
\text { flooding in the Balkans, esp. } \\
\text { Bosnia and Herzegovina, Croatia, } \\
\text { Montenegro, and Serbia. }\end{array}$ \\
\hline 9.XII & 9.XII & Tisza & HU/RS & No & - & Yes & $\begin{array}{l}\text { Snowmelt and swollen rivers flood } \\
3000 \mathrm{~km}^{2} \text { of arable land, esp. near } \\
\text { Szeged, on Tisza River in SE Hun- } \\
\text { gary. }\end{array}$ \\
\hline Dec & Dec & Koeroes & HU/RO & $\begin{array}{l}\text { Yes } \\
\text { (Flood alert) }\end{array}$ & $3 \mathrm{Dec}$ & No & $\begin{array}{l}\text { No reports found on online news } \\
\text { media. Event to be confirmed by } \\
\text { local authorities in annual EFAS } \\
\text { meeting }\end{array}$ \\
\hline
\end{tabular}

The Prut catchment is relatively symmetrical, but its largest proportion is in Romania. To the west, it has 27 tributaries, including the Poiana, Cornesti, Isnovat, Rădăuţi, Volovat, Baseu, Jijia (with a discharge of $10 \mathrm{~m}^{3} \mathrm{~s}^{-1}$, the most important), Mosna, Elan, Oancea, Branesti, and Chineja. The Jijia River is $275 \mathrm{~km}$ long, has a catchment area of $5757 \mathrm{~km}^{2}$ and an annual average flow of $14 \mathrm{~m}^{3} \mathrm{~s}^{-1}$. Its most important tributaries are Miletin, Sitna, and Bahlui. To the east, it has 32 tributaries, including the Telenaia, Larga, Vilia, Lopatnic, Racovetul, Ciugurlui, Kamenka, Garla Mare, Frasinul, and Mirnova (Romanescu et al., 2011a, b). The catchment basin has 225 small ponds, counting the Dracsani, which is the largest pond in Romania. Small ponds are used as drinking water for livestock or to irrigate rural subsistence households. 


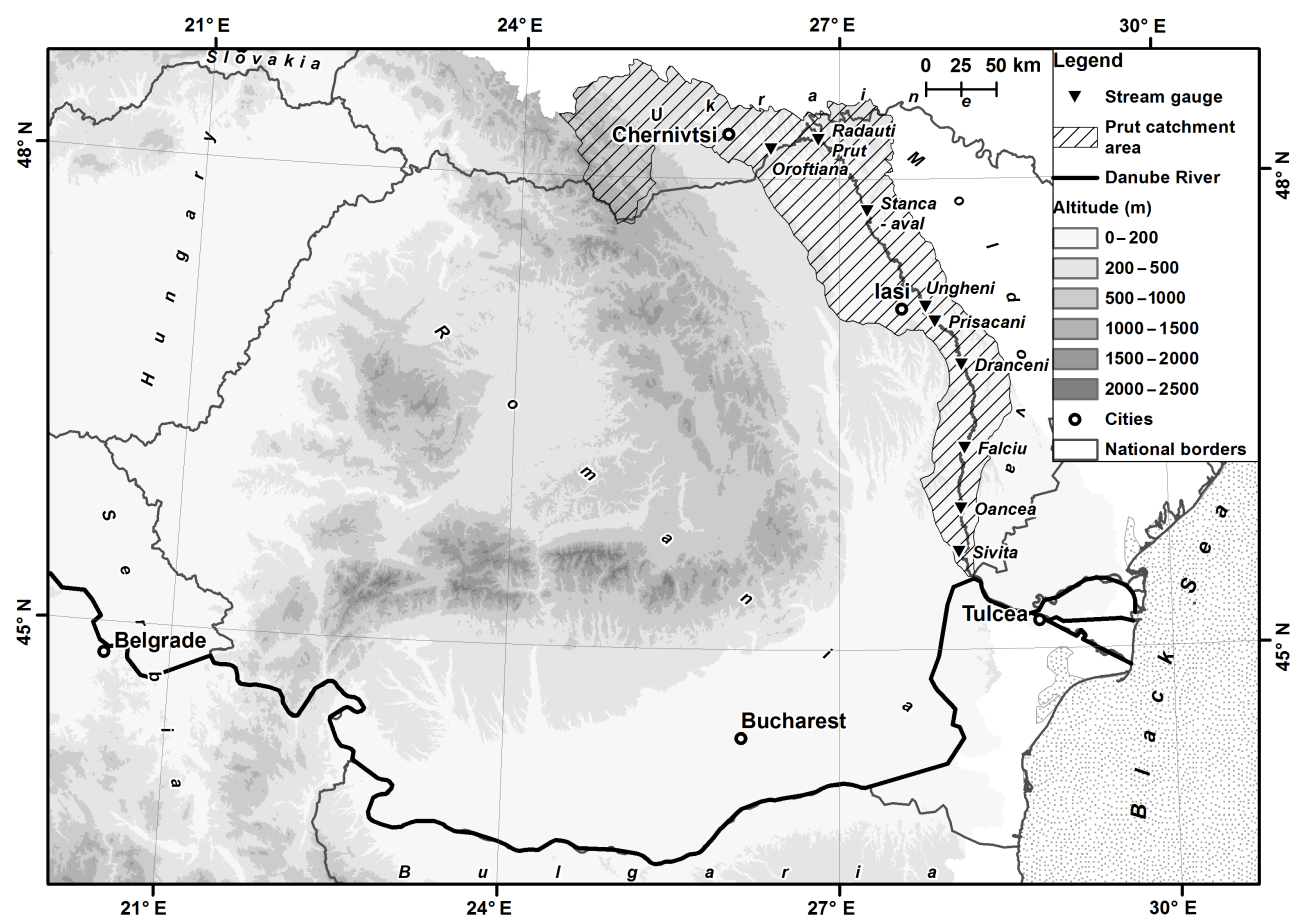

Figure 2. Geographic position of the Prut catchment basin in Romania, Ukraine, and the Republic of Moldova, and distribution of the main gauging stations.

They usually belong to individual households. Large ponds, on the other hand, have multiple uses, such as flooding mitigation (such as Ezer dam, located in Jijia River basin, which was built to protect the town of Dorohoi from flood), irrigation, fish farming, etc. They were more effective over time because of their significant surface and depth. Large ponds belong to rural or urban communities. The river also has 26 large ponds, of which the most important is the StâncaCosteşti reservoir, which has the largest water volume of the interior rivers in Romania ( 1400 million $\mathrm{m}^{3}$ ).

The topography of the Prut basin includes the Carpathians in the spring area and the Moldavian Plateau and the Romanian Plain near the river mouth. Arable land occupies $54.7 \%$ of the Prut catchment, while forests occupy $21.4 \%$, perennial cultures occupy another $13.3 \%$, and the water surface occupies only $1.19 \%$. The mean annual temperature in the Prut catchment is $9^{\circ} \mathrm{C}$, and the mean annual precipitation is $550 \mathrm{~mm}$. The mean annual discharge increases downstream, varying from $82 \mathrm{~m}^{3} \mathrm{~s}^{-1}$ at Rădăuţi-Prut to $86.7 \mathrm{~m}^{3} \mathrm{~s}^{-1}$ at Ungheni to $93.8 \mathrm{~m}^{3} \mathrm{~s}^{-1}$ at the Oancea gauging station situated near the mouth over the period 1950-2008.

Discharges in the downstream reaches of the Prut are controlled by the Stânca-Costeşti reservoir. In the Romanian Register of Large Dams, the Stânca-Costeşti Dam ranks 49th out of 246 dams in terms of height, but second in terms of active reservoir volume (1400 million $\mathrm{m}^{3}$, after the Iron Gates $\mathrm{I}$, with a volume of 2100 million $\mathrm{m}^{3}$ ). It has a surface area of 5900 ha during a normal retention level (NRL). After con- struction of the Stânca-Costeşti reservoir, floods on the Romanian parts of the Prut diminished considerably. Because the Prut has higher banks in the Republic of Moldova, this area was not affected by dam construction. The reservoir was constructed with a mitigation level of 550 million $\mathrm{m}^{3}$, allowing the mitigation of a $1 \%$ probability flood from 2940 to $700 \mathrm{~m}^{3} \mathrm{~s}^{-1}$. The damming infrastructure constructed downstream from the hydrotechnical nodes prevents the flooding of approximately 100000 ha of floodplain area (Romanescu et al., 2011a, b).

\section{Methodology}

Diverse methodology has been used to analyse exceptional floods. Hydrological data, including discharge and the water level, were obtained from the Prut-Barlad Water Basin Administration based in Iasi (a branch of the "Romanian Waters" National Administration). For catchment basins that did not have gauging stations or observation points, measurements were taken to estimate the discharge. Mathematical methods were used to reconstitute discharges and terrain measurements using land surveying equipment (Leica Total Station) to calculate the surface of the stream cross section. Most stations within the Romanian portion of the Prut catchment are automatic (Fig. 3). The recording and analysing methodology used is standard or slightly adapted to local conditions, e.g. the influence of physical-geographical parameters on run-off (Ali et al., 2012; Kappes et al., 2012; 


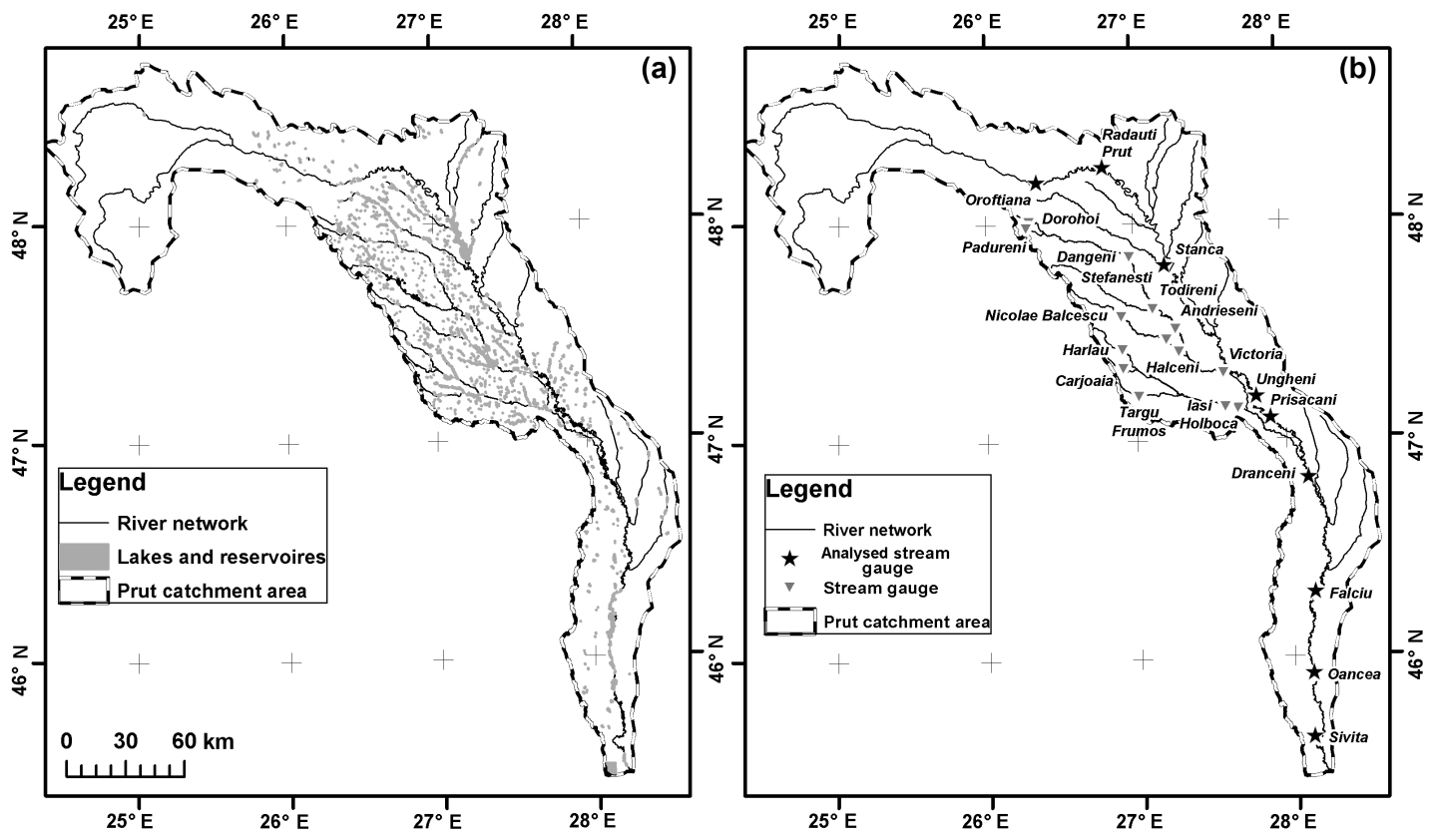

Figure 3. Main tributaries, reservoirs (left), and gauging stations (right) in the Prut River basin.

Kourgialas et al., 2012; Waylen and Laporte, 1999), the management of risk situations (Iosub et al., 2014; Delli-Priscoli and Stakhiv, 2015; Demeritt et al., 2013; Grobicki et al., 2015), the role of reservoirs in flood mitigating ( $\mathrm{Fu}$ et al., 2014; Serban et al., 2004; Sorocovschi, 2011), the probability of flooding and the changes in the run-off regime (Hall et al., 2004, 2014; Jones, 2011; Seidu et al., 2012a, b; Wu et al., 2011), flood prevention (Hapuarachchi et al., 2011), run-off and stream flow indices (Nguimalet and Ndjendole, 2008), morphologic changes of riverbeds or lake basins (Rusnák and Lehotsky, 2014; Touchart et al., 2012; Verdu et al., 2014), etc. The cartographic basis used to map altitudes and slopes is Shuttle Radar Topography Mission (Global Land Cover Facility, 2016), at a 1:50000 scale. The vector layers were projected within a geodatabase, using ArcGis 10.1. They include stream lines, subcatchment basins, and reservoirs and ponds polygons, as well as gauging station points. In order to generate the GIS layers, we applied the following methods: digitization, queries, conversion, geometries calculation (length, surface), and spatial modelling. Water levels and discharges data were processed and plotted on charts using Open Office software. We also used the Inkscape software to design the final maps and images.

All areas with gauging stations had automatic rain gauges (Anghel et al., 2011; Tirnovan et al., 2014a, b) (Fig. 3, Table 2). The heavy rains that cause flooding are recorded hourly over the course of $24 \mathrm{~h}$ according to the Berg intensity scale (Berg et al., 2009). In the areas lacking gauging stations, data were collected from the closest meteorological stations, which are automatic and form part of the national monitoring system. The water level and discharge were analysed throughout the entire flood period. For comparison, the mean monthly and annual data for the water level and discharge were also analysed. The processed data were portrayed as histograms that illustrate the evolution of water levels during the floods, including the CA (warning level), CI (flood level), and CP (danger level) flood threshold levels before and after the flood, the daily and monthly runoff, and the hourly variations of run-off during the backwater. For an exact assessment of the damage and the flooded surface area, observations and field measurements were conducted on the major floodplains of the Volovat, Baseu, Jijia, Sitna, Miletin, Bahluet, Bahlui, Elan, and Chineja rivers (Romanescu et al., 2012; Romanescu and Stoleriu, 2013b; MihuPintilie and Romanescu, 2011).

Nine gauging stations exist in Romanian sections of the Prut River: Oroftiana (near the entry, only including water level measurements), Rădăuţi-Prut, Stanca Aval (downstream), Ungheni, Prisacani, Drânceni, Fălciu, Oancea, and Sivita (which is directly influenced by the Danube, so no data were collected from this station) (Fig. 3, Table 2). The first gauging station was installed at Ungheni in 1914, and the newest station is Sivita, which was installed in 1978. Much older water level and discharge data are available from stations in other places. The data on the deviation of rainfall quantities were obtained from the Climate Prediction Center NOAA and from the scientific literature (Hustiu, 2011).

Flood damage reports were collected from city halls in the Prut catchment and the Inspectorate for emergencies in Botosani, Iasi, Vaslui, and Galati. In isolated areas, we conducted our own field research. We note that some of the reports from city halls seem exaggerated. 
Table 2. Morphometric data for the gauging stations on the Prut River (Romania).

\begin{tabular}{|c|c|c|c|c|c|c|c|}
\hline \multirow[t]{2}{*}{ Gauging station } & \multirow[t]{2}{*}{$\begin{array}{r}\text { Inauguration } \\
\text { year }\end{array}$} & \multicolumn{2}{|c|}{ Geographic coordinates } & $\begin{array}{l}\text { River length } \\
\text { from the } \\
\text { confluence }\end{array}$ & \multicolumn{2}{|c|}{ Data on the catchment basin } & \multirow{2}{*}{$\begin{array}{r}0 \mathrm{~m} \text { level of } \\
\text { gauging station } \\
\text { mrBS } \\
\text { (Metres Black Sea) }\end{array}$} \\
\hline & & Latitude & Longitude & $\mathrm{km}$ & Surface $\mathrm{km}^{2}$ & Altitude m & \\
\hline Oroftiana & 1976 & $48^{\circ} 11^{\prime} 12^{\prime \prime}$ & $26^{\circ} 21^{\prime} 04^{\prime \prime}$ & 714 & 8020 & 579 & 123.47 \\
\hline Rădăuţi-Prut & 1976 & $48^{\circ} 14^{\prime} 55^{\prime \prime}$ & $26^{\circ} 48^{\prime} 14^{\prime \prime}$ & 652 & 9074 & 529 & 101.87 \\
\hline $\begin{array}{l}\text { Stanca Aval } \\
\text { (downstream) }\end{array}$ & 1978 & $47^{\circ} 47^{\prime} 00^{\prime \prime}$ & $27^{\circ} 16^{\prime} 00^{\prime \prime}$ & 554 & 12000 & 480 & 62.00 \\
\hline Ungheni & 1914 & $47^{\circ} 11^{\prime} 04^{\prime \prime}$ & $27^{\circ} 48^{\prime} 28^{\prime \prime}$ & 387 & 15620 & 361 & 31.41 \\
\hline Prisacani & 1976 & $47^{\circ} 05^{\prime} 19^{\prime \prime}$ & $27^{\circ} 53^{\prime} 38^{\prime \prime}$ & 357 & 21300 & 374 & 28.08 \\
\hline Drânceni & 1915 & $46^{\circ} 48^{\prime} 45^{\prime \prime}$ & $28^{\circ} 08^{\prime} 04^{\prime \prime}$ & 284 & 22367 & 310 & 18.65 \\
\hline Fălciu & 1927 & $46^{\circ} 18^{\prime} 52^{\prime \prime}$ & $28^{\circ} 09^{\prime} 13^{\prime \prime}$ & 212 & 25095 & 290 & 10.04 \\
\hline Oancea & 1928 & $45^{\circ} 53^{\prime} 37^{\prime \prime}$ & $28^{\circ} 03^{\prime} 04^{\prime \prime}$ & 88 & 26874 & 279 & 6.30 \\
\hline Sivita & 1978 & $45^{\circ} 37^{\prime} 10^{\prime \prime}$ & $28^{\circ} 05^{\prime} 23^{\prime \prime}$ & 30 & 27268 & 275 & 1.66 \\
\hline
\end{tabular}

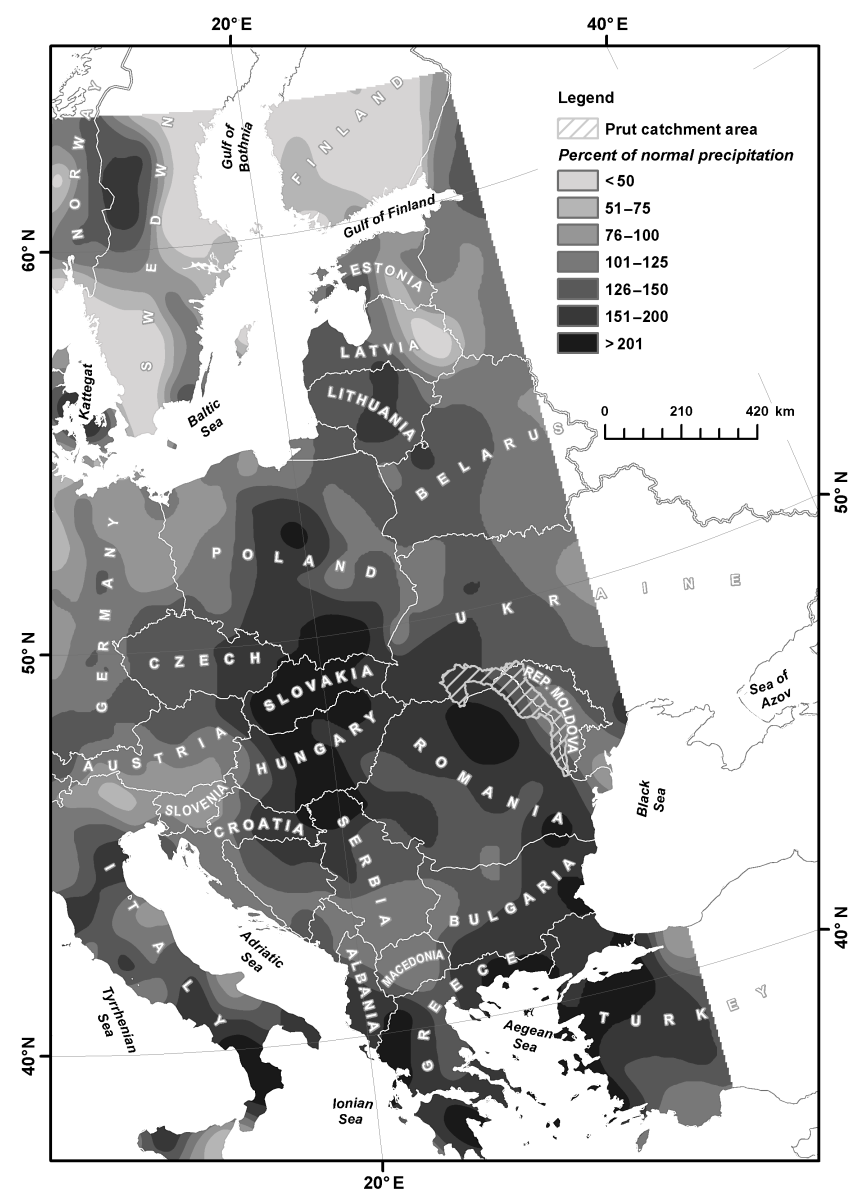

Figure 4. Cumulative precipitation for May-July (2010) interval, divided by normal precipitation - Climate Prediction Center (source data from NOAA).

\section{Results}

The majority of floods in Romania are influenced by climate factors, manifesting at local and European levels (Andrei et al., 2011; Birsan, 2015; Birsan and Dumitrescu, 2014; Birsan et al., 2012; Chendes et al., 2015; Corduneanu et al., 2016). During the last decade of June (20 June 2010) and the end of July (30 July 2010), a baroclinic area was localized in northern Moldavia. This favoured the formation of a convergent area of humidity. In this case, a layer of humid, warm, and unstable air was installed between the surface and $2500 \mathrm{~m}$ in altitude. The high quantity of humidity originated from the Black Sea, situated $500 \mathrm{~km}$ away. The warm air was generated in the Russian Plain, overheated by a strong continentality climate. The cold air from the mid-troposphere, inducted by the cut-off nucleus that generated atmospheric instability, overlapped this structure of the low troposphere (Hustiu, 2011). The synoptic context was disturbed by local physical-geographical factors, especially by the orography of the Eastern Carpathians, which led to extremely powerful heavy rains, e.g. $100-200 \mathrm{~mm}$ in $24 \mathrm{~h}$ at the sources of $\mathrm{Ji}$ jia (representing the amount that normally falls during June and July) or 40-60 $\mathrm{mm}$ in $24 \mathrm{~h}$ at the Romanian frontier with Ukraine and the Republic of Moldova. The quantity of rainfall in $24 \mathrm{~h}$ were 2-3 higher than the normal values for this period (Hustiu, 2011) (Fig. 4).

There were six main extremely rainy periods in Romania, especially in the Moldavian hydrological basins (Prut and Siret): 21-23, 25-26, 28-30 June, 3-4, 6-7 and 9 July. Rainfall quantities recorded in June were higher. The flash floods registered in northern Moldavia in 28-29 June 2010 were generated by convective systems with slow spreading. Even if the rainfalls from 29 June were lower, the floods had devastating effects because they occurred in the context of the increasing water levels from 28 June 2010. The convection was organized by a mesocyclone extended over northern 

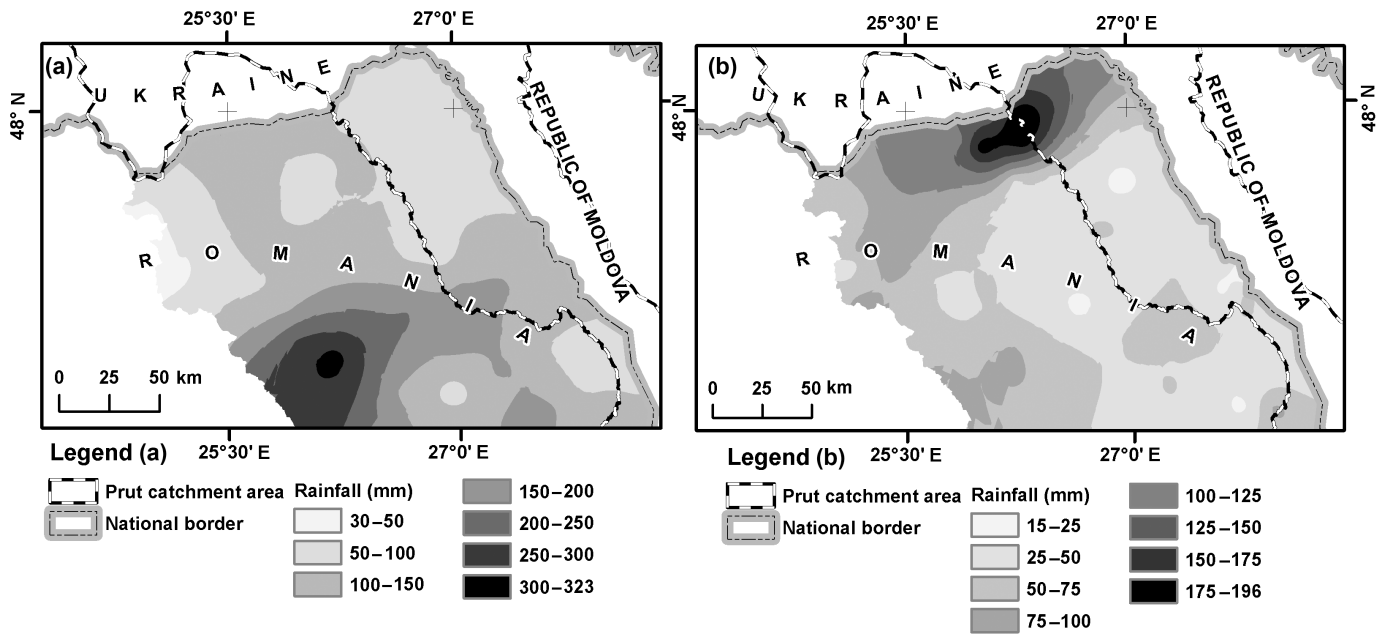

Figure 5. Cumulative precipitation amounts, in north-eastern part of Romania, from 21 to 27 June 2010 (left) and 28 June to 1 July 2010 (right).

Moldavia (the departments of Suceava and Botosani) (Hustiu, 2011).

Backwaters in the upper basins of the Prut and Siret (in north-eastern Romania) recorded during the summer of 2010 were caused by atmospheric instability from 21 June to 1 July 2010. At this time, the flood danger level (CP) was exceeded on the Prut and Jijia rivers. High amounts of rain fell during three periods: $21-24,26-27$, and 28 June1 July 2010. Precipitation exceeding $100 \mathrm{~mm}$ was recorded from 21 to 24 June ( $105 \mathrm{~mm}$, at the Oroftiana station) and from 28 June to 1 July $2010(206 \mathrm{~mm}$ at Padureni and $110 \mathrm{~mm}$ at Pomarla on the Buhai River). Very high rainfall rates occurred within a brief time frame: $51.5 \mathrm{~mm} / 50 \mathrm{~min}$. was recorded at Oroftiana station on the Prut River and $42.0 \mathrm{~mm} / 30 \mathrm{~min}$. at Padureni on the Buhai River (Romanescu and Stoleriu, 2013a, b; Tirnovan et al., 2014b) (Fig. 5).

Precipitation in the Carpathian Mountains in Ukraine initiated a series of floods in the upper Prut basin. Among the five flood peaks recorded by the Cernauti gauging station, we noted one with a discharge of $2070 \mathrm{~m}^{3} \mathrm{~s}^{-1}$ recorded on 9 July 2010 at 12:00 (UTC + 2). In comparison, another flood recorded in May did not have a very high discharge value $\left(308 \mathrm{~m}^{3} \mathrm{~s}^{-1}\right)$. In the mountainous sector, the flood warning level (CA) was exceeded only twice, with water levels of $523 \mathrm{~cm}(+25 \mathrm{~cm} \mathrm{CA})$ and $645 \mathrm{~cm}(+145 \mathrm{~cm} \mathrm{CA})$ (Fig. 6).

At the Oroftiana gauging station, where only the water levels are measured, the flood danger level (CP) was exceeded four times, with levels of $716 \mathrm{~cm}(+66 \mathrm{~cm} \mathrm{CP}), 743 \mathrm{~cm}$ $(+93 \mathrm{~cm} \mathrm{CP}), 736 \mathrm{~cm}(+86 \mathrm{~cm} \mathrm{CP})$, and $797 \mathrm{~cm}(+147 \mathrm{~cm}$ CP, on 9 July 2010 at 12:00). The flood warning level (CA) was exceeded throughout the entire flooding period (MayJuly 2010). In the month of May, the flood levels (CI) were not exceeded (Fig. 6). At the Oroftiana gauging station, one registered solely the water levels data. For all the other gaug-

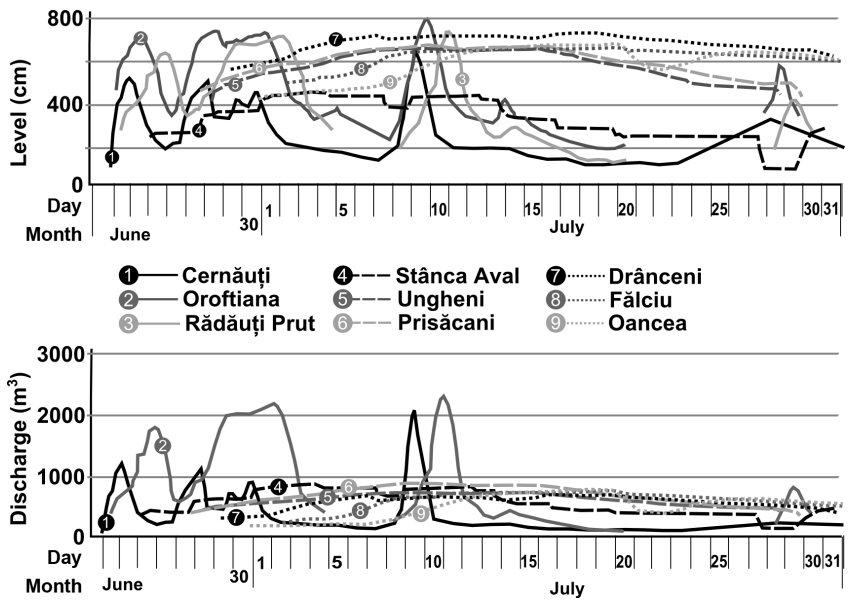

Figure 6. Water levels and discharge on the Prut River at the gauging stations of Cernauti, Oroftiana, Rădăuţi-Prut, Stanca Aval (downstream), Ungheni, Prisacani, Drânceni, Fălciu, and Oancea during the summer of 2010 .

ing stations the discharge data are being registered in addition to water level.

At the Rădăuţi-Prut gauging station, three important peaks were recorded on 26, 29 June-2 July 2010, and 10-11 July 2010. A maximum discharge of $2310 \mathrm{~m}^{3} \mathrm{~s}^{-1}$ was registered on 10 July 2010 at $9 \mathrm{pm}$. The flood danger level (CP) was exceeded four times, with water levels of $643 \mathrm{~cm}(+43 \mathrm{~cm} \mathrm{CP}$, on 25 June 2010), $685 \mathrm{~cm}(+85 \mathrm{~cm}$ $\mathrm{CP}$, on 29 June 2010), $721 \mathrm{~cm}(+121 \mathrm{~cm} \mathrm{CP}$, on 29 June2 July 2010), and $744 \mathrm{~cm}(+144 \mathrm{~cm} \mathrm{CP}$, on 10-11 July 2010) (Fig. 6).

The Stanca Aval (downstream) gauging station is controlled by overflow from the Stânca-Costeşti reservoir. This control mitigates the flood hydrographs. The maximum dis- 
charge value at this station was $885 \mathrm{~m}^{3} \mathrm{~s}^{-1}$ on 3 July 2010 . The flood level (CI) was exceeded from the beginning to the end of the flooding period. The flood danger level (CP) was exceeded from 1 to 13 July 2010, reaching a maximum water level of $460 \mathrm{~cm}(+85 \mathrm{~cm} \mathrm{CP}$, on 3 July 2010) (Fig. 6).

At the Ungheni gauging station, floods were recorded throughout the entire month of July. The maximum discharge was $673 \mathrm{~m}^{3} \mathrm{~s}^{-1}$ on 8 July 2010. Flooding continued until 5 August 2010. The flood danger level (CP) was exceeded during the 12-day period from 6 to 17 July 2010. The maximum water level was $661 \mathrm{~cm}(+1 \mathrm{~cm} \mathrm{CP})$ (Fig. 6).

Floods were also recorded throughout July at the Prisacani gauging station. The maximum discharge was $886 \mathrm{~m}^{3} \mathrm{~s}^{-1}$ on 9 July 2010. Flooding continued until 5 August 2010. The flood danger level (CP) was exceeded during the 16-day period from 4 to 19 July 2010 . The maximum water level was $673 \mathrm{~cm}(+73 \mathrm{~cm} \mathrm{CP})$ (Fig. 6).

At the Drânceni gauging station, floods were recorded over a long period from the end of June until the beginning of August. The maximum discharge was $718 \mathrm{~m}^{3} \mathrm{~s}^{-1}$ on 17 July 2010 . The flood danger level (CP) was reached or exceeded during the 18-day period from 4 to 22 July 2010. The maximum water level was $729 \mathrm{~cm}(+29 \mathrm{~cm} \mathrm{CP})$ (Fig. 6).

At the Fălciu gauging station, floods occurred throughout July and during the first half of August. The maximum discharge was $722 \mathrm{~m}^{3} \mathrm{~s}^{-1}$ on 19 July 2010 . The flood danger level (CP) was reached or exceeded during the 35-day period from 6 July to 2 August 2010. The maximum water level was $655 \mathrm{~cm}(+55 \mathrm{~cm} \mathrm{CP})$ (Fig. 6).

At the Oancea gauging station, two backwaters were recorded in July and August. The first backwaters on 19 July 2010 had a peak discharge of $697 \mathrm{~m}^{3} \mathrm{~s}^{-1}$ and the second on 27 July 2010 had a peak discharge of $581 \mathrm{~m}^{3} \mathrm{~s}^{-1}$. Both backwaters exceeded the flood danger level (CP) throughout the month of July. The maximum water level of the first backwater was $683 \mathrm{~cm}(+83 \mathrm{~cm} \mathrm{CP})$, and the maximum for the second was $646 \mathrm{~cm}(+46 \mathrm{~cm} \mathrm{CP})$ (Fig. 6). Backwaters were caused by increasing water level of Danube River, which influences the measurements results at the gauging stations situated on the downstream sector of Prut River.

The western tributaries of the Prut (within the Moldavian Plain) are numerous, but they have only modest mean annual discharges. They are periodically affected by floods following heavy summer rains. At the Stefanesti gauging station, within the downstream sector of the Baseu River, floods were recorded from 1 to 4 July 2010 . The maximum discharge was $107 \mathrm{~m}^{3} \mathrm{~s}^{-1}$ on 6 July 2010 . The flood level (CI) was reached or exceeded for 2 days. The maximum level was $355 \mathrm{~cm}(+5 \mathrm{~cm} \mathrm{CI})$ (Fig. 7). The Stefanesti gauging station is located in the downstream sector of the dam and it is directly influenced by the discharge water from the Stânca-Costeşti Lake (since 1978).

At the Padureni gauging station on the Buhai River, two backwaters were recorded in June and a secondary backwater in May. The maximum discharge was $470 \mathrm{~m}^{3} \mathrm{~s}^{-1}$ on

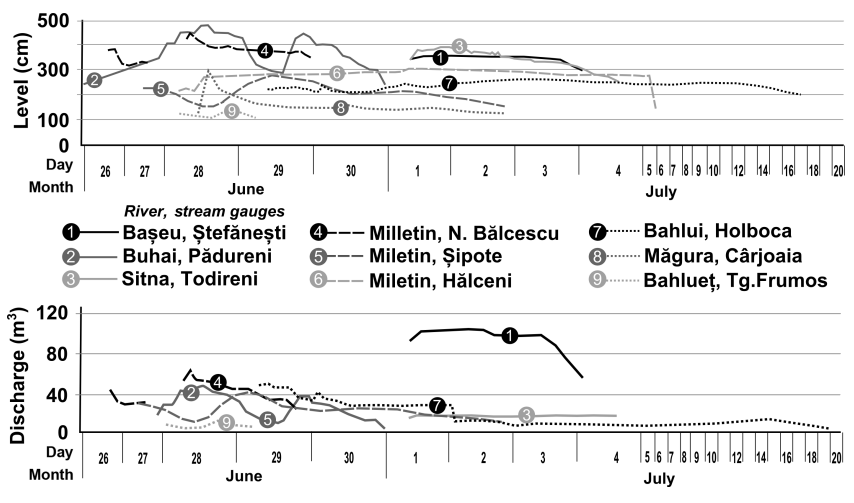

Figure 7. Water levels and discharge on the main Prut tributaries during the summer of 2010: the Baseu, Buhai, Sitna, Miletin, Bahlui, Magura, and Bahluiet rivers.

28 June 2010. The flood danger level was exceeded during both backwaters, with water levels of $470 \mathrm{~cm}(+120 \mathrm{~cm} \mathrm{CP}$, on 28 June 2010) and $440 \mathrm{~cm}$ (+90 cm CP, on 29 June 2010) (Figs. 3, 7).

At the Todireni gauging station on the Sitna River (a tributary of the Jijia), floods occurred from 1 to 4 July 2010. The maximum discharge was $19 \mathrm{~m}^{3} \mathrm{~s}^{-1}$ on 1, 2, and 4 July 2010. The flood level (CI) was exceeded on 1 and 2 July 2010. The maximum water level was $387 \mathrm{~cm}$ on 1 July 2010 . The flood warning level (CA) was exceeded on 4 July 2010 (Figs. 3, 7).

At the Nicolae Balcescu gauging station on the Miletin River (a tributary of the Jijia), floods were recorded from 26 to 29 June 2010 . The maximum discharge was $60 \mathrm{~m}^{3} \mathrm{~s}^{-1}$ on 6 June 2010. The flood level (CI) was exceeded just once, on 28 June 2010. The maximum level was $444 \mathrm{~cm}(+22 \mathrm{~cm}$ CI). The warning level (CA) was exceeded throughout the flooding period (Figs. 3, 7).

At the Sipote gauging station on the Miletin, four backwaters were recorded from 22 June to 2 July 2010. The maximum discharge was $45 \mathrm{~m}^{3} \mathrm{~s}^{-1}$ on 29 June 2010 . The flood level (CI) was exceeded from 29 to 30 June 2010. The maximum water level was $269 \mathrm{~cm}(+19 \mathrm{~cm} \mathrm{CI})$. The warning level (CA) was exceeded throughout the flooding period (Figs. 3, 7).

At the Halceni gauging station on the Miletin, floods were recorded from 28 June to 5 July 2010 . The maximum discharge was $32 \mathrm{~m}^{3} \mathrm{~s}^{-1}$ on 1-2 July 2010. The flood danger level $(\mathrm{CP})$ was exceeded during the peak discharge period, with a water level of $302 \mathrm{~cm}(+2 \mathrm{~cm} \mathrm{CP})$. The flood level (CI) was exceeded throughout the flooding period (Figs. 3, 7).

At the Carjoaia gauging station on the Magura River (a tributary of the Bahlui), one major backwater was recorded. The maximum discharge was $73.5 \mathrm{~m}^{3} \mathrm{~s}^{-1}$ on 28 June 2010 . The flood level (CI) was exceeded on 28 June 2010. The maximum water level was $280 \mathrm{~cm}(+90 \mathrm{~cm} \mathrm{CI})$ (Figs. 3, 7).

At the Targu Frumos gauging station on the Bahluet (a tributary of the Bahlui), one major backwater was recorded on 


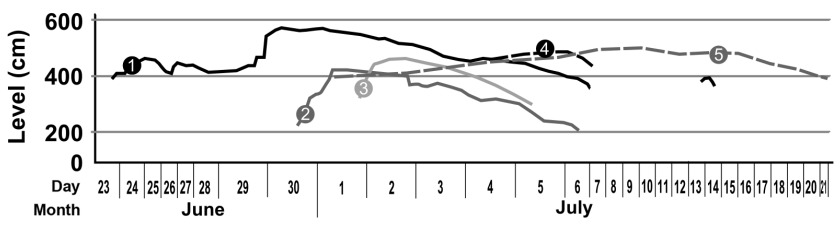

Stream gauges

(1-Dângeni 2-Todireni 3-Andrieșeni 4-- Victoria 5-- Chiperești

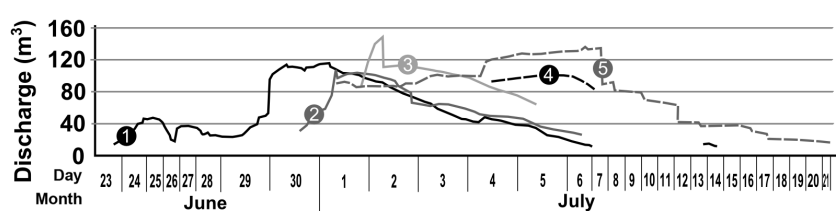

Figure 8. Water levels and discharge on the Jijia River at the gauging stations of Dangeni, Todireni, Andrieseni, Victoria, and Chiperesti during the summer of 2010 .

22 May 2010, with a maximum discharge of $48 \mathrm{~m}^{3} \mathrm{~s}^{-1}$. The flood danger level (CP) was reached on the same day and the maximum water level was $250 \mathrm{~cm}(0 \mathrm{~cm} \mathrm{CP})$. The flood warning level (CA) was exceeded throughout the flooding period (Figs. 3, 7).

At the Harlau gauging station on the Bahlui (a tributary of the Jijia), successive and increasing backwaters were recorded from 22 May to 1 July 2010 . The maximum discharge was $32 \mathrm{~m}^{3} \mathrm{~s}^{-1}$ on 29 June 2010. The flood level (CI) was exceeded throughout the flooding period. The maximum water level was $552 \mathrm{~cm}(+132 \mathrm{~cm} \mathrm{CI})$ (Figs. 3, 7).

At the Iasi gauging station on the Bahlui, floods occurred from 24 June to 4 July 2010 . The maximum discharge was $44 \mathrm{~m}^{3} \mathrm{~s}^{-1}$ on 1 July 2010. The flood warning level (CA) was exceeded throughout the flood. The maximum water level was $286 \mathrm{~cm}(+86 \mathrm{~cm} \mathrm{CA})$ (Figs. 3, 7).

At the Holboca gauging station on the Bahlui, floods were recorded from 29 June to 17 July 2010 . The maximum discharge was $50 \mathrm{~m}^{3} \mathrm{~s}^{-1}$ on 29 June 2010 . The warning level (CA) was reached or exceeded throughout the flooding period. The maximum water level was $259 \mathrm{~cm}(+59 \mathrm{~cm} \mathrm{CA})$ (Figs. 3, 7).

At the Dorohoi gauging station on the Jijia, several backwaters were recorded from 21 May to 7 July 2010. The maximum discharge was $119 \mathrm{~m}^{3} \mathrm{~s}^{-1}$ on 29 June 2010 . The flood danger level (CP) was exceeded from 29 to 30 June 2010. The maximum water level was $760 \mathrm{~cm}(+160 \mathrm{~cm} \mathrm{CP})$. The flood warning level (CA) was exceeded throughout the flooding period (Figs. 3, 8).

At the Dangeni gauging station on the Jijia, several backwaters were recorded from 22 May to 28 July 2010. The maximum discharge was $116 \mathrm{~m}^{3} \mathrm{~s}^{-1}$ on 1 July 2010 . The flood level (CI) was exceeded from 30 June to 3 July 2010. The maximum water level was $578 \mathrm{~cm}(+108 \mathrm{~cm} \mathrm{CI})$. The flood warning level (CA) was exceeded throughout the flooding period (Figs. 3, 8).

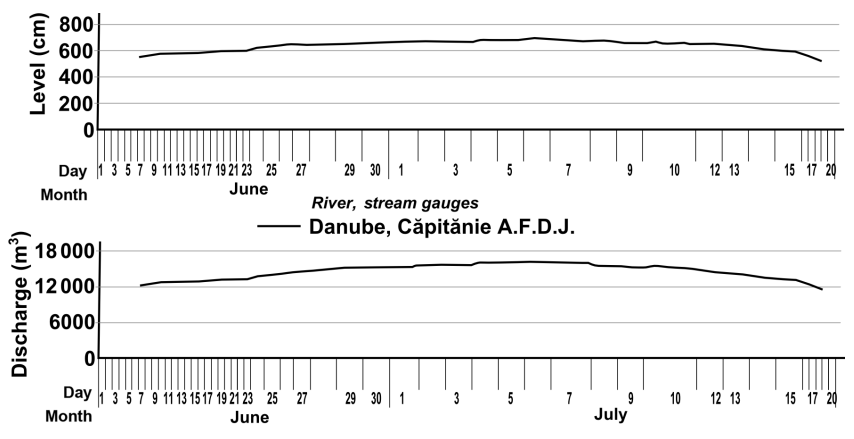

Figure 9. Water levels and discharge on the Danube at the Capitanie AFDJ gauging station in the summer of 2010.

At the Todireni gauging station on the Jijia, flooding occurred from 30 June to 6 July 2010. The maximum discharge was $104 \mathrm{~cm}$ on 1 July 2010 . The flood levels (CI) were exceeded from 1 to 4 July 2010. The maximum water level was $417 \mathrm{~cm}(+47 \mathrm{~cm} \mathrm{CI})$. The flood warning level (CA) was exceeded throughout the flooding period (Figs. 3, 8).

At the Andrieseni gauging station on the Jijia, flooding was recorded from 1-4 July 2010. The maximum discharge was $148 \mathrm{~m}^{3} \mathrm{~s}^{-1}$ on 2 July 2010 . The flood danger level (CP) was exceeded on 2 and 3 July 2010. The maximum water level was $461 \mathrm{~cm}(+11 \mathrm{~cm} \mathrm{CP})$. The flood warning level (CA) was exceeded throughout the flooding period (Figs. 3, 8).

At the Chiperesti gauging station on the Jijia, successive and increasing backwaters were recorded from 1 to 19 July 2010 . The maximum discharge was $136 \mathrm{~m}^{3} \mathrm{~s}^{-1}$ on 6 July 2010. The flood warning level (CA) was exceeded throughout the flooding period. The maximum water level was $497 \mathrm{~cm} \mathrm{(+97} \mathrm{cm} \mathrm{CA)} \mathrm{(Figs.} \mathrm{3,} \mathrm{8).}$

At the Victoria gauging station on the Jijia, flooding occurred from 4 to 7 July 2010. The peak discharge was $100 \mathrm{~m}^{3} \mathrm{~s}^{-1}$ on 5 July 2010 . The flood warning level (CA) was exceeded throughout the flooding period. The maximum water level was $485 \mathrm{~cm}(+35 \mathrm{~cm} \mathrm{CA})$ (Figs. 3, 8).

At the Capitanie AFDJ gauging station on the Danube, record floods occurred. The maximum discharge was $16300 \mathrm{~m}^{3} \mathrm{~s}^{-1}$ on 5-6 July 2010, which is a historic discharge for the Galati station. The flood level (CI) was exceeded from 26 June to 14 July 2010 (Fig. 9).

\section{Discussion}

Cumulative heavy rains from 21 to 24,26 to 27 , and 28 June to 1 July 2010 caused water levels to exceed the flood danger level (CP) by $40-150 \mathrm{~cm}$ on the Prut in the OroftianaRădăuţi-Prut sector and by $30-150 \mathrm{~cm}$ in the upper basin of the Jijia. The flood level (CI) was exceeded by 80 $110 \mathrm{~cm}$ in the middle basin of the Jijia and in its tributaries (Sitna, Miletin, and Buhai). Discharges within the lower Ji- 


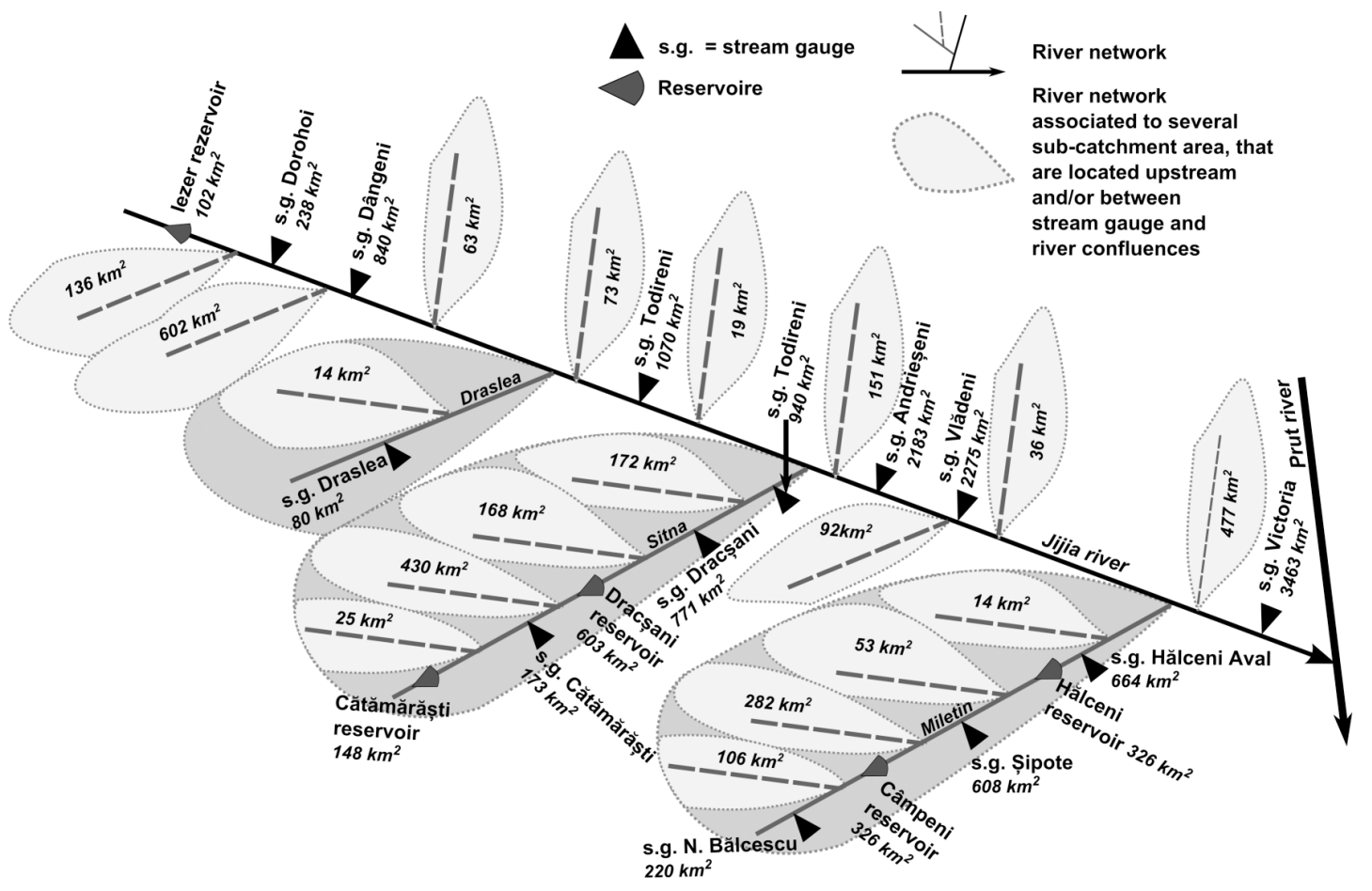

Figure 10. Distribution of subbasins within the Jijia catchment and placement of the main ponds.

jia basin were controlled by upstream reservoirs and downstream polders in the lower reaches of the Jijia.

The Oroftiana gauging station only records water level measurements. The Rădăuţi-Prut gauging station may be influenced by the water stored in the Stânca-Costeşti reservoir (which occurred during the historic flood of 2008) (Romanescu et al., 2011a, b). The Stanca downstream gauging station may be influenced by overflow from the StâncaCosteşti reservoir. The Oancea gauging station, situated near the mouth of the Prut, may be influenced by waters from the Danube. The water level registered at the Rădăutii-Prut gauging station could have been influenced by the backwaters caused by Stânca-Costeşti Lake. The most obvious case of backwaters was registered during the 2008 historic flood.

High discharge and water levels of $2310 \mathrm{~m}^{3} \mathrm{~s}^{-1}$ and $744 \mathrm{~cm}(+144 \mathrm{~cm} \mathrm{CP})$, respectively, were recorded at the Rădăuţi-Prut gauging station. The 2010 values are remarkable lower than the maximum values recorded in 2008 of $7140 \mathrm{~m}^{3} \mathrm{~s}^{-1}$ and $1130 \mathrm{~cm}(+530 \mathrm{~cm} \mathrm{CP})$ (the highest value for Romanian rivers). This value was recalculated after 2 years (through recomposed discharges), resulting in a discharge of $4240 \mathrm{~m}^{3} \mathrm{~s}^{-1}$, which is the second highest value in Romania (after the historic discharge of $4650 \mathrm{~m}^{3} \mathrm{~s}^{-1}$ on the Siret in 2005) (Romanescu et al., 2011a, b). The existence of five backwater peaks (with the second and third backwaters being weaker) clearly indicates that they were caused by heavy rains in the Carpathian Mountains in Ukraine. A volume of $200-400 \mathrm{~mm}$ of rainfall (i.e. $50-80 \%$ of the annual amount) was recorded between 1 May and 15 July 2010. Dur- ing the flood that manifested in 2008, a historic discharge value was registered for Prut River, but the bypassed water volume was low (upstream of Stânca-Costeşti Dam) because the flood duration was short. The 2010 flood registered lower maximum discharges compared to 2008, but it bypassed a larger water volume as the flood lasted longer. The flood hydrographs recorded at the Stanca Aval (downstream) gauging station features flattened and relatively uniform backwaters, mostly in the central part of the river. This behaviour is due to the influence of Stânca-Costeşti reservoir, which significantly reduced the maximum discharge at Stanca Aval $\left(885 \mathrm{~m}^{3} \mathrm{~s}^{-1}\right)$ compared to the Rădăuţi-Prut gauging station upstream of the reservoir. The water level was maintained within the upper limit recorded by longitudinal protection dams.

The Ungheni, Prisacani, Drânceni, and Fălciu gauging stations had a flattened and uniform backwater, which signifies upstream control, including some of the tributaries. The flood danger level (CP) was exceeded by a few centimetres and the floodplain was partially flooded in these areas. The high discharges recorded at the Prisacani station occurred because of waters in the upper Prut basin, including controlled spills from the Stânca-Costeşti reservoir. Downstream of the Prisacăni station, the influence of the Jijia becomes obvious: it increases the water level and lengthens the duration of floods.

Stronger floods within the middle reaches of the Prut occur because of its tributaries. Flooding on the Baseu, Sitna, Miletin, Jijia, Bahluet, and Bahlui rivers was strong, but it 


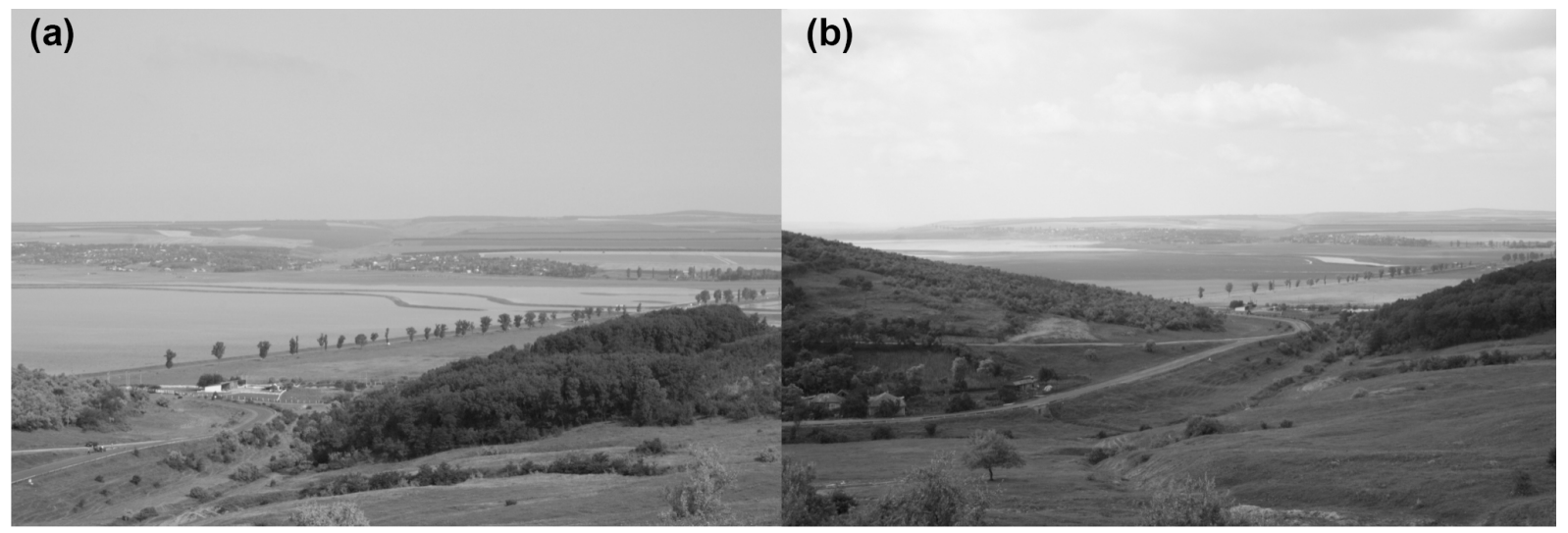

Figure 11. Polders on the Jijia and the floods recorded in the summer of 2010: storage of excess water (left) and its elimination (right).

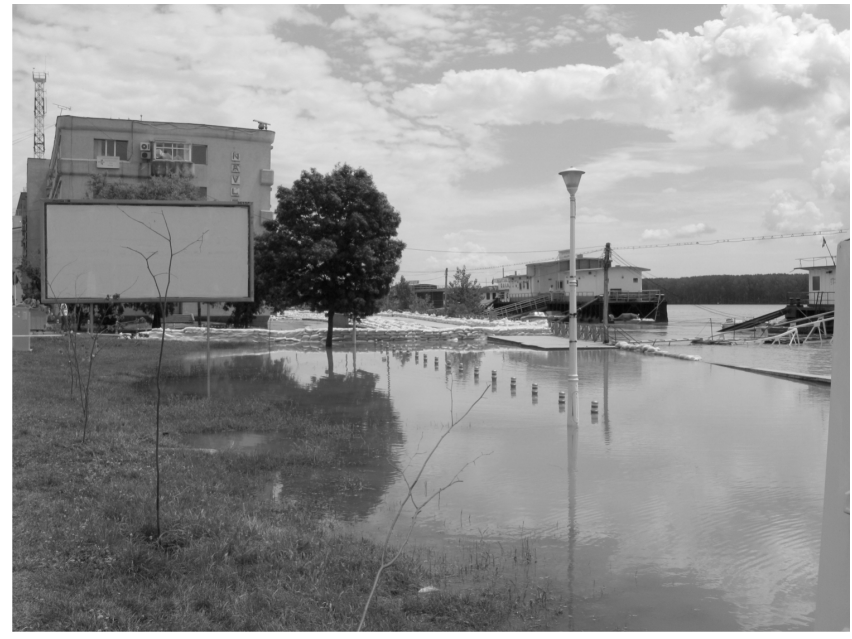

Figure 12. Flooding of the sea cliff and the NAVROM headquarters in Galati.

was mitigated for the most part by the existence of ponds (Fig. 10). Therefore, the excess water entering Romania from Ukraine entered the Stânca-Costeşti reservoir. The excess water downstream of the Stânca-Costeşti reservoir came from tributaries. Discharge from the tributaries is controlled by hydrotechnical works within each tributary's catchment. The Jijia and Bahlui catchments are $80 \%$ developed. The water levels downstream of these tributaries, in the lower reaches of the Prut, are mitigated by the extreme width of the Prut floodplain (the most important wetland of the interior Romanian rivers).

The system of polders in the lower reaches of the $\mathrm{Ji}$ jia served as an effective trap for surplus water. High discharges on the Danube, which reached a historic maximum of $16300 \mathrm{~m}^{3} \mathrm{~s}^{-1}$ at Galati (5 July 2010), would have flooded the city centre without the precincts constructed on the Jijia that stopped a portion of the floodwaters. When the floods on the Danube ceased, the water was gradually eliminated from
Table 3. Values of CA, CI, and CP for the Oancea (Prut) and Galati (Danube) gauging stations.

\begin{tabular}{lrrr}
\hline Gauging station & $\begin{array}{r}\text { CA } \\
\text { (Warning level) }\end{array}$ & $\begin{array}{r}\text { CI } \\
\text { (Flood level) }\end{array}$ & $\begin{array}{r}\text { CP } \\
\text { (Danger level) }\end{array}$ \\
\hline Oancea (Prut) & 440 & 550 & 600 \\
Galati (Danube) & 560 & 600 & 660 \\
\hline
\end{tabular}

Table 4. Maximum water levels during flooding in the summer of 2010 for the Danube compared to values from other flood years.

\begin{tabular}{llrrrrr}
\hline \multirow{2}{*}{ River } & Gauging & \multicolumn{5}{c}{ Maximum levels in the year $(\mathrm{cm})$} \\
\cline { 3 - 7 } & station & 2010 & 2006 & 2005 & 1981 & 1970 \\
\hline \multirow{2}{*}{ Danube } & Galati & 678 & 661 & 600 & 580 & 595 \\
& Isaccea & 537 & 524 & 481 & 490 & 507 \\
& Tulcea & 439 & 437 & 399 & 415 & 429 \\
\hline
\end{tabular}

Table 5. Maximum discharges during flooding in the summer of 2010 for the Danube compared to the maximum values from 2006.

\begin{tabular}{llrr}
\hline River & $\begin{array}{l}\text { Gauging } \\
\text { station }\end{array}$ & \multicolumn{2}{c}{$\begin{array}{c}\text { Maximum discharges in } \\
\text { the year }\left(\mathrm{m}^{3} \mathrm{~s}^{-1}\right)\end{array}$} \\
\cline { 3 - 4 } & & 2010 & 2006 \\
\hline Danube & Galati & 16300 & 14220 \\
& Isaccea & 16240 & 14325 \\
& Tulcea & 6117 & 5768 \\
\hline
\end{tabular}

the polders, which explains why high water levels persisted in the lower Prut for a long time (Fig. 11).

Discharge at the Oancea gauging station increased dramatically from 4-5 July 2010, coinciding with the increased discharge on the Danube at Galati. The backwater at Oancea was also enhanced by backwater from the Danube. The second backwater was caused by upstream contributions. The flood danger level (CP) at Oancea was exceeded by $+83 \mathrm{~cm}$ 


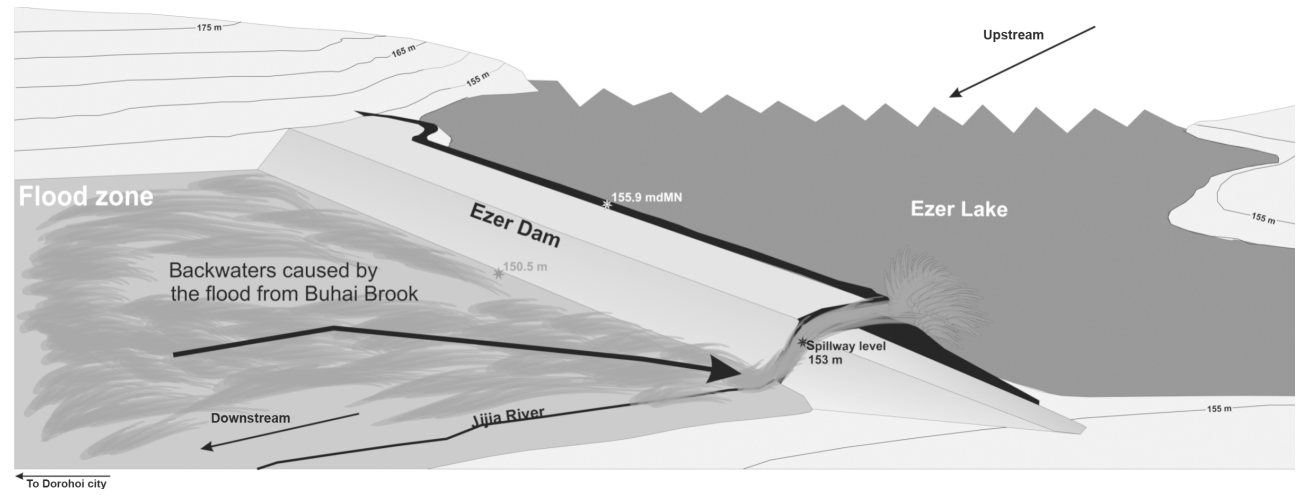

Figure 13. The "spider flow" phenomenon in which the Buhai waters climbed the Ezer dam on the Jijia, in the area of confluence of the two rivers.

Table 6. Maximum water levels during flooding in the summer of 2010 compared to 2008 and 2005.

\begin{tabular}{|c|c|c|c|c|c|c|c|}
\hline River & $\begin{array}{l}\text { Gauging } \\
\text { station }\end{array}$ & $\begin{array}{r}\text { Maximum } \\
\text { level } \\
\mathrm{cm}\end{array}$ & Day & Hour & $\begin{array}{r}\text { Difference } \\
\text { from the three } \\
\text { levels of } \\
\text { danger cm }\end{array}$ & $\begin{array}{r}\text { Maximum } \\
\text { level } 2008 \\
\mathrm{~cm}\end{array}$ & $\begin{array}{r}\text { Maximum } \\
\text { level } 2005 \\
\mathrm{~cm}\end{array}$ \\
\hline \multirow[t]{5}{*}{ Prut } & Oroftiana & 717 & 24.06 & 11 & $+67 \mathrm{CP}$ & 867 & 703 \\
\hline & & 744 & 28.06 & $11-12$ & +94 CP & - & - \\
\hline & & 737 & 1.07 & 04 & $+87 \mathrm{CP}$ & - & - \\
\hline & & 797 & 9.07 & $17-18$ & $+147 \mathrm{CP}$ & - & - \\
\hline & & 425 & 13.07 & 20 & $+75 \mathrm{CA}$ & - & - \\
\hline \multirow[t]{4}{*}{ Prut } & Rădăuţi-Prut & 643 & 25.06 & $18-19$ & $+43 \mathrm{CP}$ & 1130 & 680 \\
\hline & & 686 & 29.06 & 17 & $+86 \mathrm{CP}$ & - & - \\
\hline & & 722 & 1.07 & 23 & $+122 \mathrm{CP}$ & - & - \\
\hline & & 744 & 10.07 & $19-20$ & $+144 \mathrm{CP}$ & - & - \\
\hline Prut & Stanca downstream & 461 & 3.07 & $15-22$ & $+86 \mathrm{CP}$ & 512 & 331 \\
\hline \multirow[t]{3}{*}{ Jijia } & Dorohoi & 750 & 29.06 & 09 & $+150 \mathrm{CP}$ & 558 & 646 \\
\hline & & 722 & 30.06 & 05 & $+122 \mathrm{CP}$ & - & - \\
\hline & & 630 & 30.06 & 17 & $+30 \mathrm{CP}$ & - & - \\
\hline \multirow[t]{2}{*}{ Jijia } & Dangeni & 575 & 30.06 & 08 & $+105 \mathrm{CI}$ & 449 & 512 \\
\hline & & 579 & 1.07 & 05 & $+109 \mathrm{CI}$ & - & - \\
\hline Jijia & Todireni & 417 & 1.07 & 08 & $+77 \mathrm{CI}$ & 123 & 420 \\
\hline Buhai & Padureni & 470 & 28.06 & $19-20$ & $+120 \mathrm{CP}$ & 292 & - \\
\hline Miletin & Nicolae Balcescu & 444 & 28.06 & 15 & $+24 \mathrm{CI}$ & 286 & 334 \\
\hline \multirow[t]{2}{*}{ Miletin } & Sipote & 226 & 27.06 & 12 & $+76 \mathrm{CA}$ & 198 & 236 \\
\hline & & 269 & 29.06 & 18 & $+19 \mathrm{CI}$ & - & - \\
\hline Miletin & Halceni & 302 & 1.07 & $15-18$ & $+2 \mathrm{CP}$ & 226 & 238 \\
\hline Sitna & Todireni & 378 & 1.07 & 17 & $+28 \mathrm{CI}$ & - & - \\
\hline
\end{tabular}


(CP) during the first backwater and by $+46 \mathrm{~cm}(\mathrm{CP})$ during the second backwater (Table 3). The discharge increase and the historic values registered were caused by several factors such as the water input from the upstream sector of Prut River and the water input added by the Danube backwaters.

The city of Galati is situated at the confluence of the Prut and the Danube rivers. Thus, water at the Oancea station may be influenced by the Danube and the Prut. In the summer of 2010, the highest values of discharge and water level at Galati were recorded (Tables 4, 5). The control of flooding on the Prut meant that floodwaters in Galati reached the sector of banks where flood infrastructure had been developed (the sea cliff) as well as the lower areas of the city (Fig. 12).

Discharges and water levels in the middle sector of the Prut River (recorded at the Oroftiana, Rădăuţi-Prut, and Stanca Aval stations) rank third in the hierarchy of floods (after 2008 and 2005). Values for the tributaries (particularly the Jijia, Buhai, Miletin, and Sitna) rank first in the hierarchy of floods (Table 6).

The floods recorded in the summer of 2010 in the Buhai catchment (a tributary of the Jijia, which is a tributary of the Prut) caused backwaters to emerge at the mouth of the river. The manifestation of this backwater phenomenon is unique because the floodwaters of the Buhai River climbed the Ezer dam (on the Jijia River) and flooded its lacustrine cuvette. The phenomenon was named "spider flow" (Romanescu and Stoleriu, 2013a, b) (Fig. 13).

\section{Conclusions}

In the summer of 2010, large amount of precipitation occurred in central and eastern Europe. Heavy rains in northeastern Romania caused devastating floods in the Prut and Siret basins. Romania incurred huge economic damages. The flooding in 2010 was comparable with previous strong flood years in 2005, 2006, and 2008 in Romania. The greatest damage occurred in the middle Prut basin in the Jijia-Bahlui depression of the Moldavian Plain, where the largest arable area was destroyed.

Discharge in the downstream sector of the Prut was controlled by the Stânca-Costeşti reservoir, which ranks second in Romania in terms of active reservoir volume (1400 million $\mathrm{m}^{3}$, after the Iron Gates I, with 2100 million $^{3}$ ). It has a surface area of 5900 ha for a NRL. Under normal circumstances, the Stânca-Costeşti reservoir can retain enough water to control the downstream discharge and water level. The provision of an attenuation water volume $\left(550\right.$ million $\left.\mathrm{m}^{3}\right)$ within the lake basin is efficient in retaining a $1 \%$ probability flood (reducing it from 2940 to $700 \mathrm{~m}^{3} \mathrm{~s}^{-1}$ ). Together with the embankments located on the dam downstream sector, it helps to prevent the flooding of 100000 ha of meadow. At a normal retention level, StâncaCosteşti Lake has a total area of 5900 ha and a water volume of 1.4 billion $\mathrm{m}^{3}$.
Discharges downstream of the Stânca-Costeşti reservoir are controlled by reservoirs and retention systems constructed on the main tributaries of the Prut. We emphasize that the Jijia and Bahlui catchments have hydrotechnical works on $80 \%$ of their surface areas. The system of polders in the downstream sector of the Jijia River was used extensively to mitigate discharge and prevent the city of Galati from flooding (Galati is the largest Danubian port, situated at the confluence of the Prut and the Danube rivers).

The gauging stations in the lower sector of the Prut recorded high discharges and water levels because of excess water coming from upstream (the middle sector of the Prut). At the Oancea gauging station, however, which is situated near the discharge of the Prut into the Danube, there is a significant backwater influence. The Danube had historic discharge at Galati, which affected the water level at Oancea station on the Prut.

Floods during the summer of 2010, in north-eastern Romania, rank third among hydrological disasters in Romanian history after the floods of 2005 and 2008, which also occurred in the Siret and Prut catchments. The 2010 floods caused grave economic damage (almost EUR 1 billion in just the Prut catchment) and greatly affected agriculture. Furthermore, six people died in Dorohoi, on the Buhai River.

The 2010 floods caused a unique backwater phenomenon at the mouth of the Buhai River. Floodwaters from the Buhai climbed the Ezer dam (situated on the Jijia River) and flooded its lacustrine cuvette. The phenomenon was called "spider flow". In order to avoid such phenomena it is necessary to increase the height of the overflow structure.

Data availability. The water level and discharge data used in this research were provided by Administratia Bazinala Apa - PrutBarlad (ABA Prut Barlad). This data can be obtained with a formal request addressed to the institution mentioned above and, if accepted, it can be used only for the aim specified in the formal approach.

Competing interests. The authors declare that they have no conflict of interest.

Acknowledgements. This work was supported by the Partnership in Priority Domains project PN-II-PT-PCCA-2013-4-2234 no. 314/2014 of the Romanian National Research Council, called "Non-destructive approaches to complex archaeological sites. An integrated applied research model for cultural heritage management" - http://arheoinvest.uaic.ro/research/prospect/. The authors would like to express their gratitude to the employees of the Romanian Waters Agency Bucharest, Siret Water Administration Bacau, particularly to Jora Ionut, $\mathrm{PhD}$, a hydrologist within this research and administration agency, who was kind enough to provide a significant part of the data used in the present study. 
Edited by: M.-C. Llasat

Reviewed by: two anonymous referees

\section{References}

Ahilan, S., O'Sullivan, J. J., and Bruen, M.: Influences on flood frequency distributions in Irish river catchments, Hydrol. Earth Syst. Sci., 16, 1137-1150, doi:10.5194/hess-16-11372012, 2012.

Alfieri, L., Burek, P., Feyen, L., and Forzieri, G.: Global warming increases the frequency of river floods in Europe, Hydrol. Earth Syst. Sci., 19, 2247-2260, doi:10.5194/hess-19-22472015, 2015.

Ali, G., Tetzlaff, D., Soulsby, C., and McDonnell, J. J.: Topographic, pedologic and climatic interactions influencing streamflow generation at multiple catchment scales, Hydrol. Process., 26, 38583874, 2012.

Andrei, S., Georgescu, M., Stefanescu, V., and Valciu, C.: Blocajul atmosferic euro-atlantic si fenomenele meteorologice severe induse de persistenta sa in zona Romaniei in cursul anului 2010, Revista Stiintifica a Administratiei Nationale de Meteorologie, 77-90, 2011 (in Romanian).

Anghel, E., Frimescu, L., Baciu, O., Simota, M., and Gheorghe, C.: Caracterizarea viiturilor exceptionale din 2010, Institutul National de Hidrologie si Gospodarire a Apelor, Conferinaa Stiintifica Jubiliara, 28-30 September 2010, 178-190, 2011 (in Romanian).

Berariu, R., Fikar, C., Gronalt, M., and Hirsch, P.: Understanding the impact of cascade effects of natural disasters on disaster relief operations, Int. J. Disaster Risk Reduct., 12, 350-356, 2015.

Berg, P., Haerter, J. O., Thejll, P., Piani, C., Hagemann, S., and Christensen, J. H.: Seasonal characteristics of the relationship between daily precipitation intensity and surface temperature, J. Geophys. Res., 114, D18102, 1-9, doi:10.1029/2009JD012008, 2009.

Birsan, M. V.: Trends in monthly natural streamflow in Romania and linkages to atmospheric circulation in the North Atkantic, Water Resour. Manag., 29, 3305-3313, 2015.

Birsan, M. V. and Dumitrescu, A.: Snow variability in Romania in connection to large-scale atmospheric circulation, Int. J. Climatol., 34, 134-144, 2014.

Birsan, M. V., Zaharia, L., Chendes, V., and Branescu, E.: Recent trends in streamflow in Romania (1976-2005), Rom. Rep. Phys., 64, 275-280, 2012.

Bissolli, P., Friedrich, K., Rapp, J., and Ziese, M.: Flooding in eastern central Europe in May 2010 - reasons, evolution and climatological assessment, Weather, 66, 147-153, 2011.

Blöschl, G., Nester, T., Komma, J., Parajka, J., and Perdigão, R. A. P.: The June 2013 flood in the Upper Danube Basin, and comparisons with the 2002, 1954 and 1899 floods, Hydrol. Earth Syst. Sci., 17, 5197-5212, doi:10.5194/hess-17-5197-2013, 2013.

Bostan, D., Mihaila, D., and Tanasa, I.: The abundant precipitations in the period 22-27 July 2008, from Suceava county and the surrounding areas, Causes and consequences, Riscuri si catastrofe, 8, 61-70, 2009.

Brilly, M. and Polic, M.: Public perception of flood risks, flood forecasting and mitigation, Nat. Hazards Earth Syst. Sci., 5, 345-355, doi:10.5194/nhess-5-345-2005, 2005.
Cammerer, H., Thieken, A. H., and Verburg, P. H.: Spatio-temporal dynamics in the flood exposure due to land use changes in the Alpine Lech Valley in Tyrol (Austria), Nat. Hazards, 68, 12431270, 2012.

Chendes, V., Corbus, C., and Petras, N.: Characterisyics of April 2005 flood event and affected areas in the Timis-Bega Plain (Romania) analysed by hydrologic, hydraulic and GIS methods, 15th International Multidisciplinary Scientific GeoConference, SGEM2015, 1, 121-128, 18-24 June 2015.

Corduneanu, F., Bucur, D., Cimpeanu, S. M., Apostol, I. C., and Strugariu, Al.: Hazards Resulting from Hydrological Extremes in the Upstream Catchment of the Prut River, Water Resour., 43, 42-47, 2016.

Delli-Priscoli, J. and Stakhiv, E.: Water-Related Disaster Risk Reduction (DRR) Management in the United States: Floods and Storm Surges, Water Policy, 17, 58-88, 2015.

Demeritt, D., Nobert, S., Clake, H. L., and Pappenberger, F.: The European Flood Alert System and the communication, perception, and use of ensemble predictions for operational flood risk management, Hydrol. Process., 27, 147-157, 2013.

de Moel, H., van Alphen, J., and Aerts, J. C. J. H.: Flood maps in Europe - methods, availability and use, Nat. Hazards Earth Syst. Sci., 9, 289-301, doi:10.5194/nhess-9-289-2009, 2009.

Detrembleurs, S., Stilmant, F., Dewals, B., Erpicum, S., Archambeau, P., and Pirotton, M.: Impacts of climate changes on future flood damage on the river Meuse, with a distributed uncertainty analysis, Nat. Hazards, 77, 1533-1549, doi:10.1007/s11069015-1661-6, 2015.

Diakakis, M.: Rainfall thresholds for flood triggering. The case of Marathonas in Greece, Nat. Hazards, 60, 789-800, 2011.

European Commission: A new EU Floods Directive 2007/60/EC, available at: http://ec.europa.eu/environment/water/flood_risk/ (last access: 23 March 2010), 2007.

Feldman, D., Contreras, S., Karlin, B., Basolo, V., Matthew, R., Sanders, B., Houston, D., Cheung, W., Goodrich, K., Reyes, A., Serrano, K., Schubert, J., and Luke, A.: Communicating flood risk: Looking back and forward at traditional and social media outlets, Int. J. Disaster Risk Reduct., 15, 43-51, 2016.

Fu, X., Li, A. Q., and Wang, H.: Allocation of Flood Control Capacity for a Multireservoir System Located at the Yangtze River Basin, Water Resour. Manag., 28, 4823-4834, 2014.

Global Land Cover Facility: available at: http://glcfapp.glcf.umd. edu:8080/esdi/, last access: 11 January 2016.

Grobicki, A., MacLeod, F., and Pischke, F.: Integrated policies and practices for flood and drought risk management, Water Policy, 17, 180-194, 2015.

Hall, J., Rubio, E., and Anderson, M.: Random sets of probability measures in slope hydrology and stability analysis, J. Appl. Math. Mech.-USS., 84, 710-720, 2004.

Hall, J., Arheimer, B., Borga, M., Brázdil, R., Claps, P., Kiss, A., Kjeldsen, T. R., Kriauciuniene, J., Kundzewicz, Z. W., Lang, M., Llasat, M. C., Macdonald, N., McIntyre, N., Mediero, L., Merz, B., Merz, R., Molnar, P., Montanari, A., Neuhold, C., Parajka, J., Perdigão, R. A. P., Plavcová, L., Rogger, M., Salinas, J. L., Sauquet, E., Schär, C., Szolgay, J., Viglione, A., and Blöschl, G.: Understanding flood regime changes in Europe: a state-of-the-art assessment, Hydrol. Earth Syst. Sci., 18, 27352772, doi:10.5194/hess-18-2735-2014, 2014. 
Hapuarachchi, H. A. P., Wang, Q. J., and Pagano, T. C.: A review of advances in flash flood forecasting, Hydrol. Process., 25, 22712784, 2011.

Hufschmidt, G., Crozier, M., and Glade, T.: Evolution of natural risk: research framework and perspectives, Nat. Hazards Earth Syst. Sci., 5, 375-387, doi:10.5194/nhess-5-375-2005, 2005.

Hustiu, M. C.: Structuri mezoscalare ce produc inundatii de tip "flash flood" in Podisul Moldovei, Revista Stiintifica a Administratiei Nationale de Meteorologie, 1-16, 2011.

ICPDR: Floods in the Danube River Basin. Brief overview of key events and lessons learned, International Commission for the Protection of the Danube River, available at: https://www.icpdr.org/main/sites/default/files/nodes/documents/ icpdr_flood_report_2010.pdf, 2010 (in Romanian).

Iosub, M., Enea, A., Hapciuc, O. E., Romanescu, R., and Minea, I.: Flood risk assessment for the Ozana river sector corresponding to Leghin village (Romania), 14th SGEM GeoConference on Water Resources, Forest, Marine And Ocean Ecosystems, available at: www.sgem.org, SGEM2014 Conference Proceedings, 19-25 June 2014, 1, 315-328, doi:10.5593/SGEM2014/B31/S12.041, 2014.

Jones, J. A.: Hydrologic responses to climate change: considering geographic context and alternative hypotheses, Hydrol. Process., 25, 1996-2000, 2011.

Kappes, M. S., Keiler, M., Elverfeldt, K., and Glade, T.: Challenges of analyzing multi-hazard risk: a review, Nat. Hazards, 64, 19251958, 2012.

Kourgialas, N. N., Karatzas, G. P., and Nikolaidis, N. P.: Development of a thresholds approach for real-time flash flood prediction in complex geomorphological river basins, Hydrol. Process., 26, 1478-1494, 2012.

Lichter, M. and Klein, M.: The effect of river floods on the morphology of small river mouths in the southeastern Mediterranean, Z. Geomorphol., 55, 317-340, 2011.

Lóczy, D. and Gyenizse, P.: Fluvial micromorphology influenced by tillage on a Danubian floodplain in Hungary, Z. Geomorphol., 55, 67-76, 2011.

Lóczy, D., Kis, E., and Schweitzer, F.: Local flood hazards assessed from channel morphometry along the Tisza River in Hungary, Geomorphology, 113, 200-209, 2009.

Lóczy, D., Mátrai, I., Fehér, G., and Váradi, Z.: Ecological Evaluation of the Baja-Bezdan Canal (Hungary-Serbia) for Reconstruction Planning, Water Resour. Manag., 28, 815-831, 2014.

Merz, B., Hall, J., Disse, M., and Schumann, A.: Fluvial flood risk management in a changing world, Nat. Hazards Earth Syst. Sci., 10, 509-527, doi:10.5194/nhess-10-509-2010, 2010.

Mihu-Pintilie, A. and Romanescu, G.: Determining the potential hydrological risk associated to maximum flow in small hydrological subbasins with torrential character of the river Bahlui, Present Environment and Sustainable Development, 5, 255-266, 2011.

Nguimalet, C. R. and Ndjendole, S.: Les extrêmes hydrologiques: des indicateurs d'hydrodynamisme ou d'hydraulicité du plateau gréseux de Mouka-Ouadda sur la rivière Pipi a Ouadda (République Centrafricaine), Z. Geomorphol., 52, 125-141, 2008.

Parker, D. and Fordham, M.: An evaluation of flood forecasting, warning and response systems in the European Union, Water Resour. Manag., 10, 279-302, 1996.
Prudhomme, C. and Genevier, M.: Can atmospheric circulation be linked to flooding in Europe?, Hydrol. Process., 25, 1180-1190, 2011.

Retsö, D.: Documentary evidence of historical floods and extreme rainfall events in Sweden 1400-1800, Hydrol. Earth Syst. Sci., 19, 1307-1323, doi:10.5194/hess-19-1307-2015, 2015.

Revuelto, J., López-Moreno, J. I., Azorín-Molina, C., Arguedas, G., Vicente-Serrano, S. M., and Serreta, A.: Utilización de técnicas de láser escáner terrestre en la monitorización de procesos geomorfológicos dinámicos: el manto de nieve y heleros en áreas de montaña, Cuadernos de Investigación Geográfica, 39, 335-357, 2013.

Reza Ghanbarpour, M., Saravi, M. M., and Salimi, S.: Floodplain Inundation Analysis Combined with Contingent Valuation: Implications for Sustainable Flood Risk Management, Water Resour. Manag., 28, 2491-2505, 2014.

Riegger, T., Bieberstein, A., Hörtkorn, F., and Kempfert, H.-G.: Stabilisation of river dykes with drainage elements, Nat. Hazards Earth Syst. Sci., 9, 2039-2047, doi:10.5194/nhess-9-2039-2009, 2009.

Rufat, S., Tate, E., Burton, C., and Maroof, A. S.: Social vulnerability to floods: Review of case studies and implications for management, Int. J. Disaster Risk Reduct., 14, 470-486, 2015.

Romanescu, G., Jora, I., and Stoleriu, C.: The most important high floods in Vaslui river basin - causes and consequences, Carpath J. Earth Env., 6, 119-132, 2011a.

Romanescu, G., Stoleriu, C., and Romanescu, A. M.: Water reservoirs and the risk of accidental flood occurrence. Case study: Stanca-Costesti reservoir and the historical floods of the Prut river in the period July-August 2008, Romania, Hydrol. Process., 25, 2056-2070, 2011b.

Romanescu, G., Zaharia, C., and Stoleriu, C.: Long-term changes in average annual liquid flow river Miletin (Moldavian Plain), Carpath. J. Earth Env., 7, 161-170, 2012.

Romanescu, G. and Nicu, C.: Risk maps for gully erosion processes affecting archaeological sites in Moldavia, Romania, Z. Geomorphol., 58, 509-523, 2014.

Romanescu, G. and Stoleriu, C.: Causes and Effects of the Catastrophic Flooding on the Siret River (Romania) in July-August 2008, Nat. Hazards, 69, 1351-1367, 2013a.

Romanescu, G. and Stoleriu, C.: An inter-basin backwater overflow (the Buhai Brook and the Ezer reservoir on the Jijia River, Romania), Hydrol. Process., 28, 3118-3131, 2013 b.

Rusnák, M. and Lehotsky, M.: Time-focused investigation of river channel morphological changes due to extreme floods, Z. Geomorphol., 58, 251-266, 2014.

Schneider, C., Laizé, C. L. R., Acreman, M. C., and Flörke, M.: How will climate change modify river flow regimes in Europe?, Hydrol. Earth Syst. Sci., 17, 325-339, doi:10.5194/hess-17-3252013, 2013.

Seidu, O., Ramsay, A., and Nistor, I.: Climate change impacts on extreme floods I: combining imperfect deterministic simulations and non-stationary frequency analysis, Nat. Hazards, 61, 647659, 2012a.

Seidu, O., Ramsay, A., and Nistor, I.: Climate change impacts on extreme floods II: Improving dlood future peaks simulation using non-stationary frequency analysis, Nat. Hazards, 60, 715-726, 2012b. 
Serban, G., Sorocovschi, V., and Fodorean, I.: Riscuri induse de amenajarea hidrotehnica a iazurilor de pe Valea Sesului (Campia Transilvaniei), Riscuri si catastrofe, 1, 159-172, 2004 (in Romanian).

Sorocovschi, V.: The classification of hydrological hazards. A point of view, Riscuri si catastrofe, 9, 33-44, 2011.

Strupczewski, W. G., Kochanek, K., and Bogdanowicz, E.: Flood frequency analysis supported by the largest historical flood, Nat. Hazards Earth Syst. Sci., 14, 1543-1551, doi:10.5194/nhess-141543-2014, 2014.

Szalinska, W., Otop, I., and Tokarczyk, T.: Precipitation extremes during flooding in the Odra River Basin in May-June 2010, Meteorology, Hydrology and Water Management, 2, 13-20, 2014.

Thieken, A. H., Bessel, T., Kienzler, S., Kreibich, H., Müller, M., Pisi, S., and Schröter, K.: The flood of June 2013 in Germany: how much do we know about its impacts?, Nat. Hazards Earth Syst. Sci., 16, 1519-1540, doi:10.5194/nhess-16-15192016, 2016.

Timu, M. D.: Vara anului 2010 - intre normal si atipic, Revista Stiintifica a Administratiei Nationale de Meteorologie, 91-98, 2011 (in Romanian).

Tirnovan, A., Romanescu, G., and Cojoc, M. G.: Floods and drought - hydroclimatic risk in Suha river basin, Air and Water. Components of the Environment, 1, 188-195, 2014a.

Tirnovan, A., Romanescu, G., Cojoc, G. M., and Stoleriu, C.: Flash floods on a forested and heavily populated catchment. Case study for Suha basin (Romania), 14th SGEM GeoConference on Water Resources. Forest, Marine and Ocean Ecosystems, Section Hydrology and Water Resources, Forest, Marine And Ocean Ecosystems, available at: www.sgem.org, SGEM2014 Conference Proceedings, 19-25 June 2014, 1, 303-314, 2014 b.
Touchart, L., Azaroua, A., Millot, C., Bartout, P., and Turczi, V.: Les risques d'érosion sur les rives des étangs. Le cas du démaigrissement des plages, Riscuri si catastrofe, 11, 21-36, 2012.

Vasileski, D. and Radevski, I.: Analysis of high waters on the Kriva Reka River, Macodonia, Acta Geogr. Slov., 54, 363-377, 2014.

Verdu, J. M., Batalla, R. J., and Martinez-Casasnovas, J. A.: Assessing river dynamics from $2 \mathrm{D}$ hydraulic modelling and high resolution grain-size distribution, Z. Geomorphol., 58, 95-115, 2014.

Waylen, P. and Laporte, M. S.: Flooding and the El Nino-Southern Oscillation phenomenon along the Pacific coast of Costa Rica, Hydrol. Process., 13, 2623-2638, 1999.

Whitfield, P. H.: Floods in future climates: a review, Journal of Flood Risk Management, 5, 336-365, 2012.

Wijkman, A. and Timberlake, L.: Natural Disasters: Acts of God or Acts of Man?, London, Earthscan, 1984.

Wu, S. J., Yang, J. C., and Tung, Y. K.: Risk analysis for floodcontrol structure under consideration of uncertainties in design flood, Nat. Hazards, 58, 117-140, 2011. 